\title{
Dis abled People And Economic NeEds in the DEVELOPING WorLd
}

Majid Turmusani 


\section{DISABLED PEOPLE AND ECONOMIC NEEDS IN}

THE DEVELOPING WORLD 


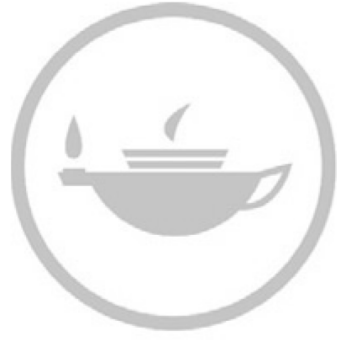

Taylor \& Francis
Taylor \& Francis Group http://taylorandfrancis.com 


\section{Disabled People and Economic Needs in the Developing World}

A Political Perspective from Jordan

MAJID TURMUSANI

United Nations Office for Project Service, Afghanistan 
First published 2003 by Ashgate Publishing

Published 2016 by Routledge

2 Park Square, Milton Park, Abingdon, Oxon OX14 4RN

711 Third Avenue, New York, NY 10017, USA

Routledge is an imprint of the Taylor \& Francis Group, an informa business

Copyright (C Majid Turmusani 2003

The author has asserted his moral right under the Copyright, Designs and Patents Act, 1988, to be identified as the author of this work.

All rights reserved. No part of this book may be reprinted or reproduced or utilised in any form or by any electronic, mechanical, or other means, now known or hereafter invented, including photocopying and recording, or in any information storage or retrieval system, without permission in writing from the publishers.

Notice:

Product or corporate names may be trademarks or registered trademarks, and are used only for identification and explanation without intent to infringe.

\section{British Library Cataloguing in Publication Data}

Turmusani, Majid

Disabled people and economic needs in the developing world :

a political perspective from Jordan

1. People with disabilities - Economic conditions

2. Sociology of disability 3. People with disabilities -

Government policy - Jordan 4. People with disabilities -

Services for - Jordan 5. People with disabilities - Jordan -

Economic conditions

I. Title

362.4

\section{Library of Congress Cataloging-in-Publication Data}

Turmusani, Majid

Disabled people and economic needs in the developing world : a political perspective

from Jordan / Majid Turmusani.

p.cm.

Includes bibliographical references and index.

ISBN 0-7546-3329-2 (alk. paper)

1. People with disabilities-Developing countries. 2. People with disabilities-Developing countries-Economic conditions. 3. People with disabilities-Jordan-Economic conditions. 4. Sociology of disability-Developing countries. 5. Sociology of disability-Jordan. 6. Islam and social problems-Jordan. I. Title.

HV 1559.D44 T87 2003

$362.4^{\prime} 091724-\mathrm{dc} 21$ 


\section{Contents}

List of Tables

vii

Preface ix

Acknowledgements $\quad x i$

Introduction $\quad$ xiii

\section{PART I: DISABILITY IN GLOBAL CONTEXT}

1. Perspectives on Disability 3

Introduction 3

Approaches to the Analysis of Disability 4

Models of Disability 5

Definitions of Disability 10

Estimates and Causes of Disability 16

$\begin{array}{ll}\text { Conclusion } & 19\end{array}$

2. Disability and Economic Needs 21

Introduction 21

The Concept of Human Rights and Disabled People 22

Poverty and Disability 25

Perspectives on Needs Assessment 34

Policy Approaches to Address the Needs of Disabled People 37

$\begin{array}{ll}\text { Rehabilitation Approaches } & 40\end{array}$

Conclusion $\quad 46$

3. Disability, Islam and the West 47

$\begin{array}{ll}\text { Introduction } & 47\end{array}$

Care or Rehabilitation: An Historical Perspective $\quad 47$

Disability Between East and West 48

Disability in Arabic and Islamic Context 49

The Impact of Western Culture on Disability in the Developing World 56

$\begin{array}{ll}\text { Conclusion } & 58\end{array}$

4. Doing Disability Research 59

Introduction $\quad 59$

Critique of Disability Research: The Emanicpatory Approach 59

Research in Developing Countries: The Participatory Methods 61

Doing Disability Research in Jordan: Research Design 64

$\begin{array}{ll}\text { Conclusion } & 71\end{array}$ 


\section{PART II: DISABILITY THEORY AND PRACTICE IN JORDAN}

5. Disability Policies and Provisions in Jordan 75

Introduction $\quad 75$

Background Information on Jordan and its Social Structure 75

The Historical Development of Disability Policy in Jordan 77

Services and Provisions Available for Disabled People in Jordan 86

Conclusion $\quad 96$

6. Perceptions of Disabled People Towards Existing Economic

$\begin{array}{ll}\text { Provisions } & 97\end{array}$

$\begin{array}{ll}\text { Introduction } & 97\end{array}$

Economic Provisions Available for Disabled People $\quad 97$

Background Characteristics of those Interviewed 101

Institutional Life of Disabled People in Jordan 106

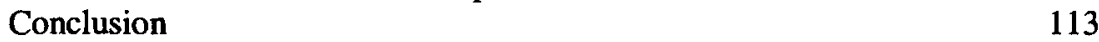

7. Economic Aspirations of Disabled People in Jordan 115

$\begin{array}{ll}\text { Introduction } & 115\end{array}$

The Economic Needs, Rights and Priorities of Disabled People in Jordan 115

Relevance of the Economic Needs to Disabled People's Lives 128

Addressing the Economic Needs of Disabled People 131

Conclusion 133

\section{PART III: CONCLUDING REMARKS}

8. The Rise of Disability Politics 137

Disability and Development 137

From the Personal to the Political Perspective 142

Developing Participatory Policy Agenda 145

$\begin{array}{lr}\text { Bibliography } & 149\end{array}$

$\begin{array}{ll}\text { Index } & 165\end{array}$ 


\section{List of Tables}

4.1 Research participants according to kind of impairment and type of economic activity

6.1 Research participants according to type of economic activity and sector of service provider

7.1 Identified principal economic needs according to kind of impairment

7.2 Secondary needs identified by research participants and first priority 


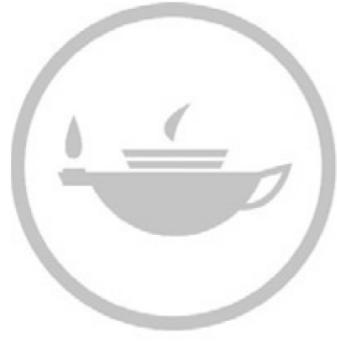

Taylor \& Francis
Taylor \& Francis Group http://taylorandfrancis.com 


\section{Preface}

Contemporary discourses on disability include recognition of the importance of cross-cultural research, however, few texts take an approach that is both comparative and descriptively detailed. This book does both. It makes an important contribution to culture-specific ethnographic detail and to theoretical development of disability that emphasizes cultural variation in developing countries. Disability only exists in reference to ability, but not necessarily a biomedical sense of ability. Taking a census of people who would be considered disabled in the US or the UK may tell us a lot about illness process, but nothing about disablement or even impairment. People are disabled if they are considered impaired and treated as disabled. There is no absolute. The cross-cultural range of acceptable variation in impairment related to disability is probably huge and almost completely unstudied. Nor can we uncritically apply an independent living model to disabled people in developing countries. This case study of Jordan gives us a fully developed description of how to focus on the perspectives of service users in planning and implementing culturally appropriate local community approaches to consumer choice and self-determination. Turmusani in both his analysis and in his presentation of his participants views moves us closer to socio-cultural models of disability. There is no unitary social model of disability or impairment, only models.

Focused on economic rehabilitation, this book also demonstrates methodological innovation in its use of a participatory approach including the use of rapid appraisal methods with disabled people in control of the production of research. Turmusani examines disability policy in Jordan and the economic domain of the lives of disabled people. It looks at the need for community based vocational rehabilitation in the context of limited government funds and general poverty. Turmusani reminds us of the essential role of disabled people in disability policy formation. It enlivens our understanding of disability as a human rights and social justice issue. Turmusani also reminds us of the essential role of disabled people in health care policy issues. We, as an international disability community, cannot afford to be locked out of these debates by medical system illiteracy born in the rejection of a medicalized view of disability. Particularly in developing countries a subtle political remedicalization of disability is necessary. We are poised at the beginning of paradigmatic shift away from a strict literal Anglo-Saxon view of independent living to more international concepts of interdependence and universal design. We move closer to a situational and temporal construction of impairment and disability. This is also true of the concept of disability culture. Is there simply a culture of disability, or is it cultures of disability?

The books three parts are well married. Part one explores the global context of disability. Part two presents the case of Jordan and looks at theory and practice. 
Part three concludes by examining the rise of disability identity and politics in developing countries with important developments in participatory policy agendas.

This book is a critical exposition of how to apply theory to practice and back again in an international context. It stretches the boundaries of disability studies to encompass sociology, anthropology, policy studies and community development. This is right where we should be.

Devva Kasnitz

University of California, Berkeley 


\section{Acknowledgements}

The work, testimony and writings of many disabled and non-disabled people have inspired the production of this book. I hope the book will be widely used in a range of developing countries as much as it will be used in the developed world and that the material will be stimulating and constructive.

There are countless number of people who helped in the process of writing and finalizing this work. I would like especially to thank disabled people who have shared their life experiences within the course of the empirical research in Jordan as well as countless other disabled people who's struggle was reported and cited in the literature of this study. For all those, I acknowledge the rich contribution they made to this work and I have greatly learned from their life insights and experiences.

A number of people have also read and made helpful comments on an early draft of this book. I would like to thanks Len Barton at Sheffield, and Ray Pawson, Carolyn Baylies, Colin Barnes, Phil Sutton, Peter Dwyer, and Jonathan Fish at Leeds.

Great and helpful comments on the final draft of this book were made by Devva Kasnitz at University of California, Berkeley. I am especially grateful to Devva for her continued support and directions throughout the writing up process of this book. I am also grateful for the support extended by Sheial Wirz at the Centre for International Child Health, London for the pre-publication endorsement of this work.

Finally, I would like to thank the editorial staff at Ashgate for their continued support and encouragement. 


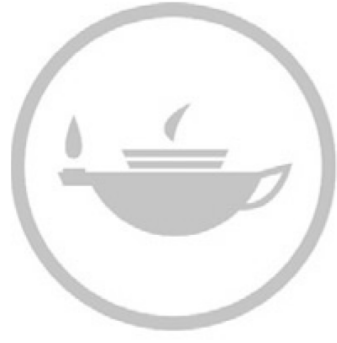

Taylor \& Francis
Taylor \& Francis Group http://taylorandfrancis.com 


\section{Introduction}

\section{Setting the Scene}

Over the last few decades, disability has been re-conceptualized as a socio-political issue rather than an individual medical problem. A variety of perspectives have emerged such as the socio-medical, interactionist and materialist accounts, all of which may be seen as social models and will be discussed latter. This study adopts a socio-political perspective similar to that of Oliver (1990), who argues that disabled people are disadvantaged by the way society is organized, contending that the solution is a policy which compensates for society's failure to accommodate disabled people's needs and which addresses various attitudinal and environmental barriers that prevent disabled people from participating in the mainstream economic life of society.

While, the social model is not the only approach to disability, it is believed that in a developing world context, such model needs to be introduced into social policy to a greater degree than is currently the case. Social policy regarding disabled people in developing countries needs to change because disability is not simply a medical issue that focuses on the individual; it is a socio-political issue. Policies introduced by the United Nations during the International Year of Disabled Persons (IYDP, 1981) and the Decade of Disabled People (1982-1993) have been endorsed by many governments in the developing world. These initiatives have emphasized the need to incorporate disability issues into social policy agendas. Given the endorsement of principles advocated by the United Nations by many developing countries, it is important that these now be translated into legislation and policy.

It can be argued that perspectives on disability within public policy in the developing world are entering a transitional phase. Initially disability was regarded as a medical and individual problem, but in recent years there has been a noticeable shift towards the socio-political approach to disability. It should be pointed out however, that earlier traditional approaches to disability in some developing countries were ambivalent, especially in societies dominated by religious beliefs (Coleridge, 1993; Miles, 1995; Ingstad and Whyte, 1995; Stiker, 1999). For example, in the Middle East including Jordan Islamic teaching reflects both positive and negative views towards disabled people. The influence of Western ideas has perpetuated the negative aspects of this view by isolating disabled people from the community into institutions. This influence of both local and global forces on disability issues in developing countries will be discussed in detail in subsequent chapters (Chapter Three). 


\section{Some General Assumptions}

This needs assessment study investigates the economic position of disabled people in the developing world and draws on the particular experience of disabled people in Jordan. It assesses how disabled people themselves evaluate their economic needs and priorities, with a secondary emphasis on the way in which existing legislation is addressing this issue. The overriding concern which underlies the study is to contribute to a change in attitudes towards disability issues, particularly as regards the economic participation of disabled people, through the adoption of a social model perspective on disability on the part of policy makers, other influentials and disabled people themselves. Such a change in attitudes should take account of the often negative ways in which disability is perceived within a particular cultural context. The main assumption which underlies this study is that there is a need to move from regarding the problem of disability and suggested solutions as being located within the individual (or from what is known as the medical model view of disability) to their being located in society (in accord with the social model perspective).

It is hoped that this empirical study will contribute to a change in attitudes toward and the treatment of disabled people in two ways. The first is pertinent to disabled people when involving them in a version of the participatory research process. It is envisaged that this can contribute towards their self emancipation by allowing them to gain more power over the production of research findings whilst simultaneously allowing respondents to become active partners, rather than passive subjects, within the research process. By involving disabled people in the research process, it is hoped that their awareness of the social perspective of disability will be heightened, which itself may have beneficial implications for their future role in society. Theoretically speaking, this type of research may provide disabled people with information necessary to facilitate a form of personal empowerment. In providing such information, Participatory Rapid Appraisal (PRA) used in this study may enable the respondents to develop a view of disability that focuses more clearly upon the constraining attitudes and structure of the wider society rather than concentrating upon personal impairments. The second is that this empirical study will provide a set of recommendations to policy makers with regard to current service provision and legislation in Jordan. As a consequence of doing disability research and disseminating the findings, it is hoped that attitudes of policy makers will be changed. Although providing policy guidelines to deal with disability issues in Jordan specifically, this needs assessment study, does also provide comparative and relevant insights, which can be valuable source of information for planning disability and development policies in other developing countries.

The study also seeks to evaluate the usefulness of the social model in providing insights into the experience of disabled people in Jordan and pointing to the need for new policy. However, this evaluation, in turn, cannot fully explain the economic life of disabled people. The key research tools used to examine the insights of the social model involved direct questions on elements of the latter and 
centred on disabled people's understanding of impairment, their role in society and social provisions for disabled people. To this extent, the social means of validation was built into the research process in such a way that the two became commensurate with and inseparable from one another. It should be noted however, that the methodology used may not permit a complete validation of the social model in the sense that the PRA method used does not allow disabled people to have full control over the research process. The social model, in this context, should be regarded as a way of understanding (theorizing) disability and can be embodied in a set of ideas or principles which may inform policies and legislation that deal with disabled people and explain their location within society (Oliver and Barnes, 1998; Priestley, 1998; Armstrong and Barton, 1999; Llewellyn and Hogan, 2000).

\section{Background of the Research}

Due to the relative lack of valid data and accurate information on the economic needs of disabled people in the developing world, it was important to conduct this research, especially through using a participatory approach capable of considering the experience of disability from the perspective of disabled people. Much of the literature in the West is critical of the existing systems of service provision for disabled people, with particular regard to economic participation. This provided the starting point for this study, as it highlights the necessity for further investigation.

An additional justification for conducting this research was the notion that disability is considered to be a developmental and a human rights issue, which should be dealt with in a comprehensive and humane way, not only through social solutions which might include charity, but also through economic provision, including employment and other financial support schemes. This means that the improvement of the situation of disabled people cannot be achieved purely by social measures. Rather, these should be combined with economic and political measures.

It is suggested, moreover, that the overall development of society can be enhanced through the improvement of the economic situation of disabled people. Breaking the economic dependency of disabled people in turns requires a set of measures and affirmative actions to remove the disabling barriers in place which prevent disabled people being integrated into mainstream society and hinders them becoming contributing and productive members in society. In this regard, Coleridge (2002) argues that disability is indeed a development issue because of the limitations of development potential where disabled people are perceived as less competent human beings. Disabled people are all too frequently left out of development plans and their voices are not heard in decision making. Disability is also a development issue because of the strong relationship between poverty and disability worldwide. 
A final impetus for carrying out this research was that the disability movement in many developing countries is still in the early stages of mobilization. Therefore, the time is right to shed light on the importance of involving disabled people in assessing their own needs. In essence this means giving them a greater critical consciousness and power to control their futures, thus enabling them to participate in the research process, and inviting their opinions on their economic situation as a human rights issue. This may help in establishing and fostering a new identity for disabled people in those countries. It is also hoped that the research findings will contribute to the consolidation of the disability movement and disabled people community in Jordan.

\section{Towards a Socio-political Model of Disability}

There are various approaches to disability including the traditional medical model, which is largely seen in functionalist writings (Parsons, 1951), as well as in interactionist accounts such as Goffman (1963), the socio medical model of disability (Bury, 1982; Williams 1991), and the social model of disability (Oliver, 1990; Barnes, 1991). These will be discussed in Chapter One. This study adopts a social model perspective similar to Oliver's (1990). Disability from this perspective is defined as socially constructed and culturally produced. Capitalism is regarded as a key element in 'creating' disability. This social model, therefore, offers a radically new way of looking at disability as located within society (economy and culture) rather than within the individual. There are variations of the social model perspective ranging from disability as a social restriction (Campling, 1981; Morris, 1996) to disability as being a form of oppression or what is termed the socio political model of disability (Abberley, 1987; Zola, 1989; Oliver, 1990; Barnes, 1991; Barton, 1996; Barton and Oliver, 1997; Priestley, 1998). The sociopolitical variant of the social model approach has emerged largely because of the limitations of the medical model to fully explain and deal with disability issues. The medical model of disability is an approach which looks at and deals with disability as an individual personal problem resulting from biological functional limitation. The solution is seen in providing care/cure interventions at the individual level. Therefore, the medical model is primarily concerned with the impaired individual (Abberley, 1987; Oliver, 1996) and is unable to take into account how the socially constructed label of 'disability' is imposed upon the individual. Detailed discussion about the social model definition of disability is provided in Chapter One within the broad discussion on definitions and models of disability.

Different writers have looked at the social model in different ways. According to Abberley $(1987,1999)$ the social model of disability involves an investigation of the way in which society disables people with impairments by failing to accommodate their differences. Oliver $(1990,1995,1996)$ sees it as a paradigm for understanding disability as socially constructed, implying that the solution is to restructure society, and particularly the economy. Barnes (1991) looks at this 
model as a way of understanding disability as a form of institutional discrimination. 'Disability' in this research, according to the socio-political version of the social model (Oliver, 1990, 1996; Barnes, 1991; Finkelstein, 1993, 1996; Barton, 1996), refers to the social and economic consequences of living with an impairment. Thus, this research adopts a social model approach, which in turn allows for the politicization of disability. The social model shifts the emphasis away from the individualistic medical approach to a more political approach in explaining and dealing with disability issues. This is discussed in more detail in Chapter One.

\section{Data Collection and Analysis}

Research goals were achieved by gathering qualitative data on the perceived economic needs, rights and priorities of disabled people in Jordan who were included in the empirical study, as well as through literature review of the economic situation of disabled people in other developing countries. The data generated from the empirical research was done mainly by using a package of participatory research tools for needs assessment called 'participatory rapid appraisal' (PRA) which will be discussed in detail in Chapter Four. This method of needs assessment can be considered to be consistent with the social model of disability in that it attempts to allow disabled people to control the research process as far as possible via their participation in setting the agenda (i.e. the attempt to draw out disabled people's views and hear their voices). In other words, insights taken from the social model are used in an attempt to fashion a research methodology which takes account of the way in which power relations may disadvantage disabled people. Conscious attempts to neutralize these disadvantages are made - at least in the research process - so that the research itself does not become a future means of disadvantaging disabled people. Therefore, the methodology used in this study is in line with the notion that identification and prioritization of needs must come from disabled people themselves, and that research should serve as a means of stimulating discussion and not just as a data collection exercise. As this approach places high value on the participation of those who are researched, there has been an attempt in this study to shift the balance in the relationship between researcher and those researched in favour of disabled people. This has been achieved by the recognition that the research process and its production is a partnership and a learning process in which both researcher and researched learn from each other. However, there is room for going further in subsequent research to democratize the research process. Finally, an emancipatory approach is most fully achieved when researchers put their expertise at the disposal of those who are researched (Oliver, 1992; Zarb, 1992; Ward and Flynn, 1995; Stone and Priestley, 1996). 


\section{A Note on the Target Group}

The target group of this research consisted of all the disabled people who were attending institutional economic schemes within Jordan. This group was stratified according to type of disability and type of economic activities. It comprised sensory and physically impaired people (blind, deaf and physically impaired people) and included disabled people who were involved in vocational training, sheltered workshops and self-employment. Another group of disabled people who were not involved in projects or programmes aimed at enhancing economic participation (i.e. from outside the target group) was also interviewed for comparative purposes. The target group was drawn from three of the five districts in the middle region of Jordan where these schemes are found. Having a target group which included the whole population of disabled people involved in economic schemes ensures the representation of gender and different geographic areas. More details relating to these variables including the number of research participants and their breakdown are discussed in the methodology chapter (Chapter Four).

\section{Outlines of the Study}

This account is organized around a number of major issues. It includes a profile of disabled people in general and disabled people in Jordan more specifically, definitions of disability, debates on disability approaches and perspectives, a discussion of attitudes towards disability, and a review of existing policies and provisions of services for disabled people in Jordan. This account incorporates issues of poverty and disability with relation to the needs approach, and discrimination against disabled people's rights across the world. The transformative potential of the participatory method (such as the PRA) when doing disability research is also discussed in some detail. Finally, this study analyses the findings regarding the perceived needs and rights of disabled people and the way they want them to be addressed.

Chapter One deals with medical and social models of disability. It is argued that although the social model is flawed, and not directly relevant to the case of other developing countries including Jordan, it is nevertheless sufficiently insightful to add an important dimension to an understanding of disability in Jordan. This chapter reviews the recent debates on disability in academia, especially the discourse regarding the social-medical views of disability, and provides a discussion of definitions of disability, and an overview of the numbers of disabled people.

Chapter Two focuses on the relationship between economic activities and disability and concludes by suggesting that economic participation is essential for disabled people. This chapter reviews the link between poverty and disability (in relation to a needs approach) and looks at discrimination against disabled people rights across the world. Different approaches to dealing with disabled people's 
needs, including their economic needs and the policies which inform them, are considered.

Chapter Three examines attitudes towards disability and disabled people in developing countries and identify factors behind society's perception of disability. This includes a number of local and global forces which will be discussed within the particular context of Jordan.

Chapter Four provides a detailed account of the methodology employed in this research, its major tools and their limitations. It assesses the attributes of this methodology compared with other methods. A brief description of the target group, as well as of the specific means of data collection and data analysis, is also included.

Chapter Five focuses on disability in Jordan with regard to existing attitudes, policies, legislation and provision of services for disabled people, as perceived by disabled people themselves and by those who served as key informants. These issues are discussed in relation to the particular cultural context of the country.

The main findings of this empirical research are presented and discussed in Chapters Six and Seven. Bearing in mind the implication of the social model which serves as the theoretical framework of this research, the presentation of results moves from the personal accounts of disabled people regarding their own impairments and how they are perceived by others, to the collective view regarding their identified economic needs (including their attitudes towards meeting these needs in terms of rights or charity and their perception of current legislation). The data on the personal experience of disabled people and their views of existing economic provision are discussed in Chapter Six. This Chapter also includes a brief account of the life of disabled people who were residents of institutions which currently provide economic support for disabled people and places this in the wider context of provision of services and policies available for disabled people in Jordan, drawing on information obtained from key informants.

Chapter Seven reviews the collective views of those who took part in the focus group discussions regarding the economic participation of disabled people. Their aspirations in respect of their perceived identified needs, rights and priorities are highlighted. The relevance of these economic needs and their impact on the lives of disabled people are also reviewed. Finally this chapter reviews the findings regarding the way disabled people wanted their needs to be addressed and highlights the problems which result when these needs remain unmet.

An overview of the economic situation of disabled people in developing countries, substantiated by research findings on Jordan, constitutes the subject of Chapter Eight. This chapter reveals the severe disadvantages experienced by disabled people as a consequence of unmet needs and lack of opportunities, especially in the economic sphere. It presents in detail the message that came through clearly from disabled people on the necessity to provide for their unmet needs and their request to be involved in the process of addressing their own issues. Other main findings are also highlighted in this chapter and a set of policy recommendations (policy guidelines) for improvement are suggested. The findings, moreover, suggest that policies and practices need to be introduced to compensate 
for disabling barriers, and that disabled people should be provided with sufficient tools to overcome such barriers. The state must be a key responsible party in this process.

It is argued that the use of Participatory Rapid Appraisal (PRA) can play an important role in raising the consciousness of disabled people about their disadvantaged situation and thus bringing them into the policy making process itself. 


\section{PART I \\ DISABILITY IN GLOBAL CONTEXT}




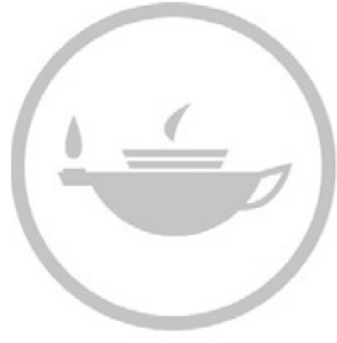

Taylor \& Francis
Taylor \& Francis Group http://taylorandfrancis.com 


\section{Chapter 1}

\section{Perspectives on Disability}

\section{Introduction}

Debate on approaches to the analysis of disability has become a distinctive feature within the academic literature on disability studies during this decade. These arguments illustrate how theoretical ideas can contribute to changes in the way we understand and discuss disability issues. In other words, these debates have an impact far beyond academic circles. The way in which the causes and outcomes of disability are discussed have an effect upon the everyday life of disabled people. For example, the emergence of the social model has politicized disabled people to bring about political change in the USA and the UK. The mobilization of disabled people through organizations such as Disabled People International (DPI), which advocates the social model, has brought disability onto the international political agenda. The shift in emphasis from the medical approach to a social model approach has given disabled people confidence and helped them to become a changing force, looking at the environment rather than themselves.

Initially this chapter will outline two different approaches, the medical and the social models of disability, although other perspectives will also be discussed such as the socio-medical model. Although this account seeks to use and advance the socio-political variant of the social model of disability, it is important to look at other contemporary approaches such as the medical model and the socio-medical model. This is because the latter approaches have special relevance to developing countries, as they are still dominant in the rehabilitation policies of these countries. The discussion reviews different perspectives on disability models within a Western context and the political impact that these models can have for influencing significant change. These models are heuristic devices through which scholars attempt to capture how a particular discourse defines, explains and implies certain policy responses relative to disability. This Chapter thus, explores how these accounts define disability, and the impact they can have in identifying the causes of disability and the way in which this is understood.

Before exploring the debate on different perspectives of disability, an overview on the origins of disability will be provided. This is because an understanding of the social construction of disability cannot be fully achieved without considering its historical development, and how the notion of disability is created and constructed. Such knowledge is important for explaining the origins of disability and tracing the way policies and provision for disabled people have been formulated over time. 
This overview notes that impairment has existed throughout humankind's history and disabled people have generally been subjected to disadvantage and discrimination on the grounds of their impairments (Rieser and Mason, 1990; Barnes, 1995; Stiker, 1999). There have been different perspectives on disability across the ages as well as between different contemporary societies. The ways in which these different perspectives and models take account of the economic role of individuals and the economic implications of disability varies. For example, the medical view argues that disabled people were excluded from the mainstream economy because they were seen as unable to contribute to the well-being of society due to their functional limitations. The social view in contrast, explains the exclusion of disabled people from the economy in terms of discriminatory policies rather than as a result of a lack of ability (Oliver, 1990). Discussion of both perspectives will be provided in subsequent sections.

\section{Approaches to the Analysis of Disability}

Broadly speaking, debates on theoretical explanations of disability can be found in the following four categories. The first is the functionalist account, rooted in Parsons' account of the sick role (French, 1994, Barnes, 1996), or what is termed in this book the 'medical model'. Disability in this view is the physical condition of the impaired body and this can therefore be regarded as an individualist materialist approach (Priestley, 1998). The term materialist is used in different ways within the academic debate on disability in the West. In this study, the materialist account refers primarily to the physical barriers in society when talking about the social model of disability. But, in Priestley's account, it can also refer to the individualistic medical model when talking about the physical limitations of the body.

The second is the interactionist account which appears in Goffman's analysis of institutionalization and stigma (1963). Here the emphasis centres on disabled people's adaptation to their impairment, and the attitudes of non-disabled people to those with impairments. In this account, although there is still something "wrong" with the impaired individual, it is society which separates people out on the basis of their impairments (Goffman, 1963). In this sense, the emphasis has been shifted from the individual to the way society treats people with impairments. However, this account has been criticized by materialists such as Oliver (1990), Abberley (1987) and Barnes (1996) for not explaining why society responds to disabled people in negative ways.

The third is the social model of disability, also known as the 'socio-political model' which is largely advocated by English writers like Abberley (1987), Oliver (1990, 1995, 1996), Finkelstein (1993, 1996), Barnes $(1991,1996,1997)$ and Barton (1998). It holds that disability is the material product of socio-economic relations and that the emphasis should be put on society's disabling barriers and power relations rather than on the individual's impairment. 
Finally, the postmodernist account argues that while the material situation is important, the circumstances of impairment also remain important too. Shakespeare (1994) contends that it is necessary to move away from society to an account of the relationship between disabled people and the social construction of society's cultural values. Postmodernist analysis, however, remains important in this research as this study is concerned with people's experience to some extent (but only with reference to the impact on social policy). The Postmodernist account within this context is an approach which theorizes the social world as created through the interplay of multitudinous 'texts'. The work of construction never ends, but is continually subject to challenge and re-interpretation, and is the realm within which power is manifested (Fox, 1993). Postmodernist analysis suggests that there are no more structures to shape our lives. For example, class no longer structures people's lives. Society has changed and people are free to reinvent themselves drawing on their experiences.

This book uses a materialist analysis to show how the social model is relevant to the economic life of disabled people in Jordan. The material situation of disabled people in Jordan can be explained with reference to their isolation, the economy, politics and social attitudes. Our analysis thus incorporates a focus on the economic, political and social situation. The kind of questions asked in this account are about the respondents experiences of their social conditions rather than their personal experience of the body and pain which is often the focus in feminist and postmodernist analysis.

\section{Models of Disability}

Social policies relating to disabled people can be understood with reference to three different approaches: the isolation model, the medical model and the social model. The first of these, the 'isolation model', looks negatively at disabled people and considers superstitious explanations for individual problems. From this perspective, marginalization from the community with minimum intervention to keep the disabled person alive is the best solution. The 'medical model' recognizes the need for catering for those with impairments, but lacks confidence in disabled people's abilities and equal rights, yet considers the problem as personal. From this perspective, disability is looked at as an individual problem that requires voluntary interventions for cure or care. Therefore, a major implication is that the labour market should compensate employers for loss of productivity by good practice and state subsidies and they should be encouraged to hire disabled people (Oliver, 1990). The 'social model' revolves around the issue of equal opportunities for disabled people. A major implication which follows from this model is that the labour market should promote policies to facilitate the removal of physical barriers and that anti-discrimination legislation should be put in place.

In the following analysis, emphasis is put on how the three models, define and seek to understand the causes of disability and what the implications of each is for 
disabled people in terms of employment, services including welfare provision, and political and social rights.

\section{The Isolation Model}

Firstly, the isolation model, which is sometimes supported by religious institutions in different cultures, is based on the view that disability is a punishment (Coleridge, 1993). According to this view, disabled people are unfortunate and different and it is therefore assumed that they should be kept away from the sight of the community (Ingstad, 1995). Ironically keeping those with impairments institutionalized, while catered for, can imply a privileged situation for those people who receive services, especially in times of widespread poverty.

From this perspective, 'culture' and religion largely affect the way in which people view disability. In Jordan for instance, people with impairments were and may still be excluded from mainstream society largely on the grounds of religious explanations. Because many developing societies are dominated by religious beliefs, disability is frequently seen as a punishment from God and as conferring stigma, especially in families who have disabled members. A common response is to hide them from sight (Oliver, 1990; Miles, 1994; Devlieger, 1999a; Ghai, 2001).

However, the importance of religion (as a factor in shaping the wider society's attitudes to disabled people) is not confined to developing countries. Within Western society, Judeo Christian values have influenced the way in which disability has been perceived. An ambivalent view of disability is part of all major religions which often view disability as related to sin on the one hand (Hoddle, 1999; DAA, 1999; Stiker, 1999), while on the other, disabled people are regarded as needing care within the context of charity. In the West, disability since the sixteenth century has largely been conceptualized in terms of economic capacity, but Western society's attitudes towards disabled people are also influenced by history and religious ideologies.

\section{The Medical Model}

The individualistic medical model defines disability as a medical defect which implies a human need to be cured or cared for. A person with an impairment is someone who is deviant from the norm of health and as a result needs medical services to eliminate or treat the condition (Hunt, 1966; Coleridge, 1993; Lunt and Thornton, 1994).

The medical model focuses attention on individual impairments and suggests care or cure interventions to deal with them. By locating the problem of disability with the individual, impairment becomes an individual responsibility. Society's responsibility towards disabled people is thus minimized (Dalley, 1991). Having said that, it is equally important to note that if the problem is located with an individual, then the solution may involve the individual being assisted and trained to cope better. In this sense, this model, though putting the onus on the individual, may imply the need for society to provide programmes to assist the individual. 
In this book, the construction of disability is explained in relation to the economy. Disabled people are excluded from mainstream society due to their functional limitations and their inability to perform an economic role. This functional explanation goes back as far as Greek and Roman times which both recognized the functional limitations of individuals, though they responded to these limitations in different ways. The Greek economy was built on slavery, and this, together with their cultural beliefs which glorified physical perfection, led to negative attitudes towards those with impairments. The Greeks and Romans recognized the functional limitations of impaired people and sought to make them economically productive members of society by developing 'scientific' treatments for their impairments. This particularly applied to deaf people and those with epilepsy (Garland, 1994; Barnes, 1996; Stiker, 1999). Later in industrial societies when Darwinist ideas predominated, economic and even physical survival for people with impairments was as precarious, and any weak or dependent individual was likely to be excluded (Oliver, 1990). In such societies, those who were out of work because of their impairments were likely to be excluded from the mainstream on the grounds that they were unproductive members and thus considered a drain on resources.

The medical model, by arising in this context, has, reflected individualistic social values, enabling it to have a legitimate influence in the formulation of wider policies of the day. Social values, expressed in policies and general attitudes towards those with impairments, encouraged an individualistic and medical approach to disability (Rieser and Mason, 1990; Oliver and Barnes, 1998; Abbereley, 1999).

\section{The Social Model (the socio political model)}

The 'social model' defines disability as a form of oppression imposed on people who have certain forms of impairments. From this perspective, society plays a major role in creating disability. Here capitalism is regarded as key to the shaping of the modern form of disability (Oliver, 1990; Barnes, 1991; Coleridge, 1993). Disability is seen as an artificial construction and the environment is presented as being the site of problems including physical, built architecture, attitude, organizational dimensions and work practice. From this perspective, the solution, as Oliver (1990) suggests, is a policy which focuses on removing the physical and social barriers rather than compensation.

This model explains the construction of disability with reference to social factors and regards disability as a result of the disabling barriers of society, especially the economy. Although people with impairments are seen as 'unfortunate' because they are regarded as unable to enjoy the material and social benefits of modern society, particularly in terms of their limited participation in the economic life of the community (given the central position of work in Western society) (Hunt, 1966; Abberley, 1987; Thomas, 1989; Gadacz, 1994; Barnes, 1996), this does not lessen their worth or provide reasons for their oppression in 
any way. Nor does it give the right to anybody to make choices for them or speak on their behalf (Oliver, 1990; Zarb, 1992; Rachman and Grant, 1994; Oliver and Barnes, 1998).

In Western culture, disability from the perspective of the social model, is seen as a product of a disabled person's relationship to the economy. In her analysis of the creation of disability in the UK, the USA and Germany, Stone (1984) argues that disability is constructed as an administrative category to control the labour supply and that it is not a flexible category. The concept of disability within capitalism is perceived as essential to the development of the work force in industrial societies.

Stone (1984) argues that all societies function through a work mechanism, and that populations are divided into those who can work and those who cannot. Over time, in some societies a work-based system emerges for those who can work and a needs-based system for those who cannot, such as disabled people. Society takes on an obligation to support those who may be excluded from the paid labour market such as certain women, children and disabled people. Those unable to work may be admitted to the needs based system by being defined as a disabled person In this sense, the category of disability determines access to a needs based system of welfare which is, in turn, supported by those who do work. As highly industrialized countries become more complex, the needs-based system is expanded, so that more and more disabled people become entitled to welfare and fewer people will work. Therefore, societies may face many financial crises as they supports more and more disabled people, who are not working. In this respect both Stone (1984) and Oliver (1990) argue that disability is linked to production and accumulation within capitalist systems. Disability, thus, is linked to work and those who are said to be disabled are excluded from the labour market. Disability from this perspective is considered to be an outcome of the development of Western industrial society, whereby disabling policies exclude those with impairments from employment on the grounds that they are unable to cope with the new factory work system (Finkelstein, 1980). As a result, disabled people became segregated from the mainstream of economic and social life of capitalist societies into residential institutions.

The social model is becoming widely accepted by many in academic circles as well as within the community of disabled people. Many have advocated this model, especially those with impairments such as Oliver, Barnes, Finkelstein and others. It is argued that the strength of the social model is due to it seeing beyond the specific impairment of individuals. It encompasses social, economic, cultural, legal, and political dimensions of disability from a human rights perspective. It emphasizes that disabled people have rights to define the services they require. Its advocates carry out research on legislation and policies, and campaign to confront prejudice and discrimination (Zola, 1989; Hastie, 1997).

The social model has not just developed in the last few years, but has been advocated since the 1970s albeit in a range of variant forms. Some variants, such as the ecological view of Albrecht (1992), and the socio/medical view of Bury (1991, 1996), Williams (1996) and indeed Goffman (1963) become neglected in 
favour of a more socio-political approach which Oliver $(1990,1992,1996,1997)$ Barnes (1991, 1996) Barnes and Mercer (1997) Finkelstein (1983) Barton (1996) Barton and Oliver (1997) and others advocate. It is important to show how these views relate to our analysis in this study. A contribution which sheds lights on this issue is Exploring the Divide (1996).

The 'Introduction' of Exploring the Divide compares the social model with the socio/medical model advocated by people like Bury and Williams (1991). It is argued that the socio/medical model begins with an individualistic view focusing on the body and is built on personal tragedy theory, whereby the individual is looked at as deviant and abnormal (Barnes, 1996). In many developing societies such as in Jordan, this model is particularly relevant as the country's social policy is predominantly influenced by the socio/medical model. Yet this model is limited in a number of respects. It is based on the formal definitions of disability of the World Health Organization (WHO), assesses needs from an illness perspective, and focuses on the meaning and experience of chronic illness or, from what Bury (1982) has called 'individual biography'. Medical sociologists such as Bury, argue that the social dimension of disability is taken into consideration in the WHO definition in respect of the term 'handicap' as will be discussed below. However, from the social model perspective, the social dimension taken by the WHO is limited because it is not concerned with the political consequences of impairment and disability (Barnes and Mercer, 1996). In fact it is questionable whether the socio-medical model is concerned with the ways in which society may disadvantage and discriminate against disabled people.

This book advocates the use of the social model to facilitate disabled people's needs being met in developing societies. Accordingly, the study attempts to promote the rights of disabled people and the responsibility of society in catering for their needs as a priority. In Jordan for example, provision for disabled people at present is not based on rights, but rather on charity. Adoption of a social model has significant implications for further policy. It could be argued in line with Oliver (1990), Abberley (1999), and Armstrong and Barton (1999) that the medical model explains disability as something wrong with the individual. They are regarded as not quite human, as unable to compete in the labour market because of their impairments, therefore, as needing charity. The rights perspective on the other hand, states that disabled people, as full human beings, have rights to participate in the workplace and that the workplace should be structured accordingly as a social obligation (Thornton and Lunt, 1995).

The social model, however, has recently been under scrutiny and criticism by both disabled and able-bodied people alike and even by some within the disability movement (Oliver, 1996). Some disability theorists arguing from a feminist (Morris, 1991; French, 1993; Crow, 1996; Fawcett, 1999; Thomas, 1999) as well as some post modernists (Pinder, 1996; Marks, 1997a; Shakespeare, 1994) have raised questions and suggested developments which they regard as necessary to make the model relevant to disabled people's lives. Namely, they have advocated the inclusion of discussion of impairments and personal experience within the 
social analysis of disability. The feminists' critique of the social model is strongly resisted in turn by Oliver and Finkelstein, who explain that including the personal experience of impairment will dilute the effectiveness of the social model (Finkelstein, 1996; Oliver, 1996). Others, criticized the social model for not sufficiently noting the experience of disabled people from racial backgrounds (Fine and Asch, 1990; Dossa, 1999; Asch, 2000).

While disability, from the social perspective, is about social issues, this does not rule out the fact that disabled people have medical needs as emphasized by the medical model. Thus the medical model has an important place in explaining and dealing with impairment related issues at least in respect of the provision of medical needs. However, as this study addresses the economic problems of disabled people in Jordan, there is a need to look at the social organization of Jordanian society, and the introduction of policies that focus on the material conditions of disabled people in terms of employment and benefits issues. For this purpose, the perspective of the social model is crucial.

\section{Definitions of Disability}

There have been recent debates in the West about the use of language and the distinction between impairment and disability, especially within the academic community and among disabled people. How different models define and explain disability will have implications for policies and provision made for disabled people. There are two conflicting positions in this context, the oldest of which was introduced by WHO (Wood, 1981) and which is broadly consistent with the medical model of disability. It revolves around the official classification of impairment, disability and handicap or what is known as the International Classification of Impairment, Disability and Handicap (ICIDH). The second definition, consistent with the social model of disability, was introduced by an organization of disabled people (the Union of Physically Impaired Against Segregation, UPIAS, 1976), and then adopted by the disabled people's movement in the form of the Disabled People International (DPI, 1986) and the British Council of Organizations of Disabled People (BCODP). Basically the second looks at disability as socially constructed and culturally produced form of oppression and in that sense it is regarded as an outcome of society's attitudes and policies. Therefore, it advocates the restructuring of the community as a solution to problems faced by disabled people including those related to the economy and labour market participation.

\section{A Medical Approach to Disability; the WHO Definition (ICIDH1)}

Traditional definitions of disability such as the International Classification of Impairment, Disability and Handicap (ICIDH) developed by the WHO (Wood, 1981), locate the problems of disability with the individual. The WHO definition 
(ICIDH1) sees impairment as abnormality in function and defines it in the context of health experience as:

'any loss or abnormality of psychological or anatomical structure or function'.

Disability in the context of health experience means:

'not being able to perform an activity considered normal for human beings: any restriction or lack (resulting from impairment) of ability to perform an activity in the manner or within the range considered normal for a human being'.

Handicap in the context of health experience is defined as:

'the inability to perform a normal social role and is defined as: a disadvantage for a given individual resulting from an impairment or disability that limits or prevents fulfillment of a role that is normal (depending on age, sex, social or cultural factors) for that individual' (WHO, 1980).

Definitions have implications for the range of solutions suggested for disability problems (Oliver, 1990). To the degree that the adoption of the ICIDH1 perpetuates an individualistic medical interpretation of disability, this may in turn perpetuate discrimination against disabled people. The implications of using the medical definition can be seen in UN aid programs and the WHO's policies in developing countries, which have mainly focused on creating institutions that contain impairment, rather than facilitating the social inclusion of disabled people Marks (1997b) argues that the ICIDH1 does not acknowledge the cultural aspects of disability, which often determine the perceived level of 'handicap' in many societies as well as the resources available for rehabilitation. Nor does it include all categories of disabled people, such as alcoholics or those with emotional difficulties (Ingstad, 1995).

The WHO's (ICIDH1) definition can be interpreted as a political statement in the sense that it focuses on the individual rather than society. Adherence by professionals to a medical definition has reinforced their ability to exert control over their clients and maintain their own professional expertise (Barton, 1989; Gregory, 1997). Such definitions label those who are different, make them into the 'other' (Barton, 1996) and then justify subjecting them to more control (i. e. the ICIDH1 is based on the notion that people with perceived impairments are less than complete individuals). In a society where high value is placed on physical condition and independence, such as in Jordan, the use of such definitions may internalize attitudes of rejecting those with disability. For these reasons, many disabled people nowadays, especially in the developed world, reject classifications which imply either negative status or stigma (Zola, 1993; Harrison, 1995; Gregory, 1997; Pfeiffer, 1999).

The medical model definition and more specifically the WHO's (ICIDH1) are vulnerable to severe criticism from both disabled and non disabled writers, especially from the supporters of the social model of disability (Davis, 1986; 
Oliver, 1990; Barnes, 1991; Marks, 1997b; Pfeiffer, 1998). As Oliver (1990) points out, the medical model of disability does not take into account social, environmental and economic factors affecting disability. Nor does it consider the personal experience of disabled people. This may be in part because it has been formulated by people who are not accountable to disabled people's organizations Those who formulated the ICIDH1 were not representing disabled people's organizations and therefore did not directly draw on the collective experience of disability and discrimination (Davis, 1986). Although individuals by themselves can have their own definition, it is likely that these definitions will vary between different individuals. When people come together and have shared experience, then they can produce a definition which is collectively acceptable from a social model perspective.

In summary, the WHO definition of impairment, disability and handicap presents a number of difficulties. By implying that it is the disabled person who is abnormal and unable to perform social roles, it locates the problem within the body rather than within the disabling society. Moreover, the WHO's definition has been seen to be unworkable in a variety of cultural contexts, because there is no such universal as an able-bodied human being. A cultural relativist approach in defining disability might therefore, be more appropriate than a universalizing one.

\section{Looking Beyond the Individual: the Social Model Definition}

Official understanding and practice in many developing countries including Jordan in dealing with disability issues do not formally recognize a social definition of disability (Coleridge, 1993). However, it is evident from recent policy that governments have begun to acknowledge the social and political dimensions of disability as we will see in the coming chapters (Wiman, 1996; Stone, 1996, and 1999; Devlieger, 1999b; Metts and Metts, 2000; Shang, 2000; Priestley, 2001; Ghai, 2001; Chimedza, 2001; Turmusani, 2002). In trying to move this position further, this study adopts the 'social model' definition of disability based on the UPIAS definition of disability (UPIAS, 1976).

The social model definition originated in the West, but has increasingly been adopted by disabled people's organizations across the globe. UPIAS first put forward the social definition in the mid 1970s in which disability was looked at as socially constructed and defined as a

'disadvantage or restriction of activity caused by a contemporary social organization which pays little attention to people with physical impairment and discounts their participation in the mainstream of social activity' (UPIAS, 1976).

Later this definition was broadened to include other impairments and adopted by BCODP and DPI (Campbell and Oliver, 1996; Barnes and Mercer, 1997).

UPIAS (1976) and DPI (1986) have strongly advocated a social model definition in favour of one consistent with the medical model in order to move the focus from impairment to disability, and to highlight disabling social, 
environmental and attitudinal obstacles, rather than lack of ability. This definition does not deny the functional limitation of impaired people, but rather argues that their limited participation in life's activities is because of the disabling barriers of society and not due to lack of abilities. Therefore, it looks at impairment as the functional limitation affecting a person's body and mind and disability as the loss or limitation of opportunities due to society's failure to address that functional limitation (Davis, 1986; Oliver, 1990; Barnes, 1991; Barton, 1996).

The social perspective adopted in this study, besides having political power, can point to the way in which economic, political and social practices exclude disabled people enables me to make generalizations as a social scientist. It also affirms that disabled people have the same rights as other members of society and that they should be in charge in managing their lives as well as participating in the community.

\section{The Politics of Meaning}

The notion of ' the politics of meaning' has been given special attention within the debate on the social model of disability in current literature on disability studies. This is because definitions of disability typically reflect the way a given society perceives disabled people and the suggested solutions put forward to deal with it (Oliver, 1992). The potential political impact that definitions can have on creating disability is largely recognized by the British movement of disabled people. From this perspective therefore, the problems of impairment become disability when they are defined as such and the act of definition is disabling because people are denied a support system (i. e. a person with an impairment may experience disability because of social response to the impairments and not simply because of any lack of functioning they have). Oliver (1992), Bury (1996) and Coleridge (1993) refer to the role of definitions in the exclusion of disabled people. Oliver (1996), for example, in Exploring the Divide points out that disability is the product of definitions and practices that seek to exclude individuals regarded as deviant from society. He argues that if research is not based on definitions of disability which disabled people's organizations' themselves find acceptable, it will fail to address their concerns. Instead it becomes a means of oppressing disabled people. It is the organization of social values, the environment and the relations of production that make people disabled, through exclusion and discrimination. Similarities may be drawn here between the disadvantaged position of disabled people with other minority groups in Western society that also face disadvantage and exclusion, for example, black people and women (Oliver and Barnes, 1998).

There are different implications of definitions for policies and the provision of services for disabled people. Within traditional societies dominated by religious values, a particular perspective on disability may dominate whereby some impairments are neither regarded as disability nor are those affected confronted by disabling societal barriers (Coleridge, 1993). In a rural environment, for example, 
people with intellectual impairments such as dyslexia would not be disadvantaged in that they do not have to read. People in Jordan, for instance, who have dyslexia, do not have problems getting a job, because there is a lot of manual work they can do, and very little services sector employment.

In the UK, although the same situation can apply, the impact of the traditional individualistic medical definitions is apparent in educational policies as well as in employment. Visually impaired, deaf, and physically impaired people are now being integrated into the mainstream of schools, but people with severe 'learning difficulties' are often still excluded. Employment policies in the UK are also increasingly geared towards the inclusion of people with physical impairments (Oliver and Barnes, 1998). Computer technology has revolutionized employment for a section of disabled people. Similarly, research in Australia found that the use of appropriate technology has enabled disabled people to undertake employment that is information-based, helping in their economic integration (Pell, 1997). Such utilization by disabled people of technology in the workplace is still limited in many developing countries. Evidence from the literature shows that the use of technology by disabled people in the workplace in Jordan applies only to those people who are blind, through computerized telephone units in some government departments (Khatib, 1989). It can be argued that in Jordan technologies such as the use of computers could liberate many more disabled people and help integrate them into the mainstream of society.

A Note on Language The distinction between impairment and disability and the use of language has been the subject of much debate among proponents of the social model. It has also been the subject of debate between UPIAS, BCODP and DPI. While UPIAS and BCDOP are concerned with impairment and disability, the DPI position refers to disability and handicap. The DPI uses disability to mean impairment and handicap to mean disability (although DPI Europe uses impairment and disability rather than disability and handicap) (Oliver and Barnes, 1998).

Morris (1993) in Independent Lives, likens impairment and disability to the issue of sex and gender. Sex is the biological element of human existence and gender is the social dimension associated with personhood. Impairment applies at the biological level and disability at the social level. In this sense, it should be noted that someone's condition is impairment, while disability relates to the social consequences of living with that impairment. According to WHO terminology, however, for someone with mild hearing difficulties, impairment is about their hearing capability. Disability is about the way that the loss of hearing affects them so they can hear less than what other people can hear, and handicap is the consequences of that dysfunction. However, Oliver (1996) in Exploring the Divide, questions the conceptual clarity of the WHO definitions of impairment, disability and handicap and argues that it portrays disability as involving both the individual and the social dimension. Because the word handicap is so offensive, disability is a blurred concept and because it sits in the middle and refers to functional limitation, the question of causality is blurred. It can then be argued that impairment causes 
disability (that is dysfunction) alleviating social responsibility for providing facilities to overcome that disability. When using the term 'people with physical impairment', the issue of causality is similarly blurred, becoming a non-political issue, in the sense that a term such as 'visual impairment' focuses the attention on an individual problem and not society's barriers. Oliver would agree that people with physical impairments may not be able to walk, but they are disabled by society's failure to provide appropriate mobility aids. Thus, a flight of stairs create disability. Because of the way that the notion of impairment is constructed by the WHO, impairment is located at the biological level, disability refers to functional limitations resulting from impairment and handicap is regarded to be a result of impairment or disability. Thus the WHO definition places the causes of disability and handicap on the shoulders of the individual. However, when the distinction is made between impairment as a biological phenomenon and disability as the social creation in accordance with the social model, then clarity is ensured because in the former causality is linked to the individual, whereas in the latter it is linked to society. While in the medical model the problem of disability is resolved by looking at the individual, in the social model it is resolved by looking at society. In this book a social model perspective is adopted whereby impairment refers to the physical, sensory and visual limitations of individual, and disability refers to the consequences of society's failure to address people's needs, including the economic ones.

\section{A Revised WHO Definition}

In recent years, the original WHO definition has been increasingly criticized. This is mainly because it has failed to provide a universal framework for determining who is disabled and who is not. Moreover, Oliver (1990) argues that it does not provide the academic with an appropriate tool for understanding the problem at hand. Such inconsistencies lead one to ask whether the supporters of the WHO's definition are talking about an individual's limitations or society's failure to address their needs. Such ambiguities can only serve to limit the usefulness of conceptual tools available to the academic in the above regard. It is important to recognize that disability is the relationship between individual impairment and societal restrictions that are imposed by social organization (Oliver, 1996).

In response to such critics, the WHO has now revised its definition. The revised ICIDH2 uses the three fold terms of impairment, activity and participation Impairment means:

'a loss or abnormality of body structure or of a physiological or psychological function'.

Activity means:

'the nature and extent of functioning at the level of the person. Activities may be limited in nature, duration and quality'. 
Participation means:

'the nature and extent of a person's involvement in life situations in relationship to impairments, activity, health conditions and contextual factors. Participation may be restricted in nature, duration and quality' (http://www.who.ch)

It can be noted that the impairment dimension has been separated into two: function and structure; disability has been replaced by the activity dimension and handicap has been reformulated as participation. Contextual factors refer to elements in the environment including people. Although the ICIDH2 has new terminology to use which takes into account the social aspect of impairments, it is still based on a medical understanding of disability similar to that of the ICIDH1, in the sense that both ICIDH1 and ICIDH2 begin from the body's systems (Pfeiffer, 2000). The ICIDH1 uses impairments (as signs and symptoms) as parts of a constellation which forms a disease - a biological approach; whereas the ICIDH2 system uses them as consequences which are part of the disablement phenomenon and extends the approach into a 'biopsychosocial' one. The overall aim of the ICIDH2 is to provide a common framework for understanding and communicating the different dimensions of disablement and health conditions. This classification covers any disturbance in terms of functional changes associated with health conditions at body, person and society levels.

WHO's revised definitions use new terms that stem from the social model (http://www.who.icidh/icidhtrg/sld002). The new International Classification of Impairment, Disability and Handicap (ICIDH2) is universal in form, in the sense that it does not only apply to disabled people, it applies to everybody. It takes on board the issue of environment and recognizes the role of social factors in the production of disablement. The ICIDH2 has emerged largely because of the limitations associated with the ICIDH in evaluating people's health care needs on the basis of diagnosis alone. The ICDIH2 is now being assessed to determine its usefulness in measuring the social consequences of health conditions. This radical approach challenges the traditional existing approach of WHO mentioned earlier (ICIDH). It defines impairment and disability in terms of capability rather than limitation. In this sense, this approach relates to the notion of human capabilities and functioning and is embedded in a human rights context. The ICIDH2 embodies a synthesis of both the medical and social approaches to disablement. Each dimension of disablement is conceptualized as an interaction between intrinsic features of the individual and the person's social and physical environment (Bury, 1996). Thus, disablement in this new definition (WHO's ICIDH2) is understood as an identifiable variation of human functioning (Pfeiffer, 1998).

\section{Estimates and Causes of Disability}

This section looks at the question of how much disability there is, noting the problem with estimates which have emerged about prevalence within and between 
countries. There is great difficulty involved in estimating the prevalence of disability across different societies. Among factors which affect such estimates are firstly, differences in cultural definitions of what constitutes impairment; secondly, differences in the nature of the built environment, which may present obstacles and can create disability; thirdly, differences in the level of medical technology and its capability of reducing the impact of illness conditions; fourthly, differences in level of poverty which affects rates of illness which can lead to impairments, and finally differences in the ability of countries to carry out comprehensive surveys yielding accurate information on the extent of impairments and disability.

Given these difficulties, estimates must be treated cautiously. On the basis of the WHO definition of impairment and disability (ICIDH1), supplemented by information from some national surveys, estimates have been proposed about the prevalence of disability. Different estimates of the proportion of disabled people throughout the world, ranging between four cent and 17 per cent of the global population, with variations between developed and developing countries and urban and rural areas.

\section{Numbers of Disabled People}

The way in which disability is understood and perceived is a significant factor underlying differences in estimates of prevalence and incidence of disability. In this sense, social values and criteria in different cultures play a major role in identifying impairments within a given population. Johnson (1991) argues that developing countries often use different criteria in defining impairment from those of developed countries. For example, only cases of visible impairment were considered as disability in the only Jordanian national survey conducted in 1979, as until very recently some impairments such as speech defects and learning difficulties were not defined as disabilities. In addition, limited funds and lack of qualified staff contributes to the inaccuracy of surveys in developing countries Constituting a major obstacle in terms of the logistics to conduct proper research and ensure that the target group has been reached efficiently.

However, the figure of ten per cent of any given community being disabled is generally considered acceptable by UN organizations. On this basis, UNICEF (1989) estimated that there are 514 million disabled people in the world, $75-80$ per cent of whom live in developing countries. The current global estimate for the prevalence of impairment is four per cent for developing countries and seven per cent for developed countries (Coleridge, 1993; Helander, 1993). This difference may be explained with reference to the differing medical and rehabilitation achievements between the developed and developing countries (Helander, 1993). It may also be partly due to a high child mortality rate, so that fewer people with impairments to survive into adulthood. Coleridge (1993) and Harris-White (1996) argue that with respect to the social environment, the prevalence of disability is also higher in urban than rural areas when a definition of functional limitation of disability is used. This is because urban life imposes more constraints on those 
with impairments. There are more environmental barriers in urban areas than rural areas in developing countries. For example, some individuals with learning difficulties in urban areas are disadvantaged and disabled by their inability to read and write. Moreover, within an urban environment in developing countries, the number of disabled people may be higher due to the lack of adequate sanitation, which may lead to the spread of disease causing impairment. In terms of numbers, therefore, there are more disabled people in developing countries than the developed world, but proportionately developed countries have more disabled people.

Many of the factors noted above as affecting estimates apply in the case of Jordan and will be discussed further in part two of this book. Until recently only visible impairments tended to be regarded as leading to disability in Jordan. In consequence, an early survey found a rate of only half per cent disabled people in Jordan (QAF, 1979). This underestimation of the prevalence of impairments is important and worrying because it can serve as an excuse for inadequate attention being given to the issue by policy makers. In 1989, the official number of disabled people was 132,549 including 23,000 children, according to figures from Jordan's Ministry of Social Development (MSD, 1989). This estimate puts Jordan in line with countries such as the Philippines and Zimbabwe which both have an estimate of disability around four per cent, and in fact this estimate is in line with the most recent global estimate of disability in developing countries of four per cent. However, if the WHO estimates that ten per cent of any given community are disabled or impaired is used, Jordan has up to 400,000 disabled people out of the total population of four million. Accepting the problem of accuracy, national surveys and estimates are important as they show the size of the problem within a society and put pressure on policy makers to provide for the needs of those with impairments.

\section{Causes of Impairment}

Let us now look very briefly at causes of impairment world-wide, highlighting the relation between certain kinds of impairments and the underdevelopment context, on one hand, and between certain kinds of disability and the industrial world, on the other, bearing in mind that from a social model perspective impairment does not cause or lead to disability (Oliver, 1990; Beresford, 1996). Oliver (1990) and Disability Awareness in Action (DAA)/UNESCO (1995) argue that impairments which result from infectious diseases, poverty, ignorance, and the limitations of medical treatment for certain kinds of blindness and deafness are likely to be more common in 'third' world countries, especially those cases which can be explained by poverty related causes such as malnutrition and lack of clean water. In contrast, impairments which result from aging, accidents at work, road and home accidents, heart conditions, spinal injuries, are more likely to be common in the industrial world. 
The DAA/UNESCO Report (1995) shows that the major causes of disability on a global basis including malnutrition, accidents, infectious and non-infectious diseases, and congenital diseases as below.

- Malnutrition accounts for 100 million and makes 20 per cent of the disabled population;

- Accidents, including trauma and war accounts for 78 million and make $\mathbf{1 5 . 6}$ per cent of disabled people;

- Infectious diseases account for 56 million and make 11.2 per cent of disabled people;

- Non-infectious diseases account for 100 million and make 20 per cent;

- Congenital diseases account for 100 million or 20 per cent.

A further proportion of impairment is also caused by factors related to the environment such as pollution, improper use of medical technology, and violation of human rights (Despouy, 1991; Inclusion International, 1996).

These causes interestingly, support the relationship between poverty and impairments as they (malnutrition and many infectious and non-infectious diseases) which mostly results from poverty, are among the most important factors causing impairment. In the Middle East, UNICEF (1998) identified iodine deficiency as a widespread problem that requires action. For example, in Jordan it was estimated that 38 per cent of Jordanian children are iodine deficient, which was until recently the world's leading cause of mental retardation.

\section{Conclusion}

Impairment has existed throughout history, but disability as oppression and as a contentious issue has been debated within Western culture only in recent years. In the post-war context, disability has been associated with the work of functionalists (Parsons, 1951) and interactionists (Goffman, 1963) or what is now termed as the medical model. During the last three decades different approaches to disability have emerged, notably the social model of disability.

This chapter has provided a review of recent debates concerning approaches to disability, especially regarding the medical and social models of disability. How these models define and explain disability has had implications for the provision of services to disabled people and estimates of prevalence of disability in a given society.

The definitions that different models embody impact on the way disability is perceived by society and the way in which services are provided to disabled people. For example, when disability is defined from a medical view, then it is understood as an individual problem and the emphasis is put on the individual as the site of alteration. In contrast when disability is defined from the social model, it 
is understood as a societal issue and society then becomes actively involved in the provision for those with impairments.

This chapter has highlighted the value of using and advancing the social model of disability and has emphasized the positive political implication of this model on disabled people. Until recently, there has been little recognition in developing countries of the ability of disabled people to participate in economic life (Shang, 2000; Chimedza, 2001), in spite of some successful cases of disabled people with mild impairments having been integrated into the labour market. Approaches to disability remained largely influenced by medical understanding (Coleridge, 1993) Nevertheless, there has been a growing realization over past decades influenced by Western professionals who are involved in this field, of the need to adopt the social model of disability. This increasing awareness has often been expressed by the introduction of disability policies in a number of developing countries as we shall see in the case study on Jordan. 


\section{References}

\section{Contents}

Index $137 \quad 137 \quad 142 \quad 145 \quad 149165$ 


\section{Bibliography}

Abberley, P. (1987), 'The Concept of Oppression and the Development of a Social Theory of Disability', Disability, Handicap and Society, Vol. 12(1), pp. 19-55.

Abberley, P. (1992), 'Counting Us Out: A Discussion of the OPCS Surveys', Disability, Handicap and Society, Vol. 7(2), pp. 139-55.

Abberley, P. (1999), The significant of work for the citizenship of disabled people, Centre for Disability Studies, Leeds, http://www.leeds.ac.uk/disability-studies/archiveuk/.

$\mathrm{Abu}, \mathrm{M}$. (1989), The History of the Hashemite Kingdom of Jordan: The Creation and Development of Transjordan 1920-192, Ithaca Press, London.

Acton, N. (1983), 'World Disability: The Need for a New Approach', in O. Shirley (ed.), Poverty and Disability in the Third World, Third World Group and AHRTAG, Fromme, pp. 79-87.

ADA (1992), American with Disabilities Act, 42, section 2.2(c), pp. 28.

Afrooz, G. (1978), An Assessment of Attitudes of Regular School Teachers Towards Exceptional Children in Iran, Unpublished Doctorate Dissertation.

Albrecht, G. (1992), The Disability Business: Rehabilitation in America, Sage, Newbury Park, London.

Ali, A. (1991), The Meaning of The Holy Qur'an (transl.), Ammana Corporation, Brentwood, Maryland.

Armstrong, F. and Barton, L. (1999), Disability, Human Rights and Education: Crosscultural Perspectives, Open University Press, Buckingham.

Asch, A. (2000), 'Critical Race Theory, Feminism and Disability: Reflections on Social Justice and Personal Identity', The Ohio State Law Journal, Vol. 62(1), pp. 391-425.

Barnes, C. (1991), 'Institutional Discrimination Against Disabled People and the Campaigning for Anti-Discrimination Legislation', Critical Social Policy Journal Vol. 12(1), pp. 5-22.

Barnes, C. (1992), 'Qualitative Research: Valuable or Irrelevant?' Disability, Handicap and Society, Vol. 7(2), pp. 139-155.

Barnes, C. (1996), "Theories of Disability and the Origins of the Oppression of Disabled People in Western Society' in L. Barton (ed.), Disability and Society: Emerging Issues and Insights, Longman, London, pp. 43-60.

Barnes, C. and Mercer, G. (1996), 'Introduction: Exploring the Divide', in C. Barnes, and G. Mercer (eds), Exploring the Divide: Illness and Disability, The Disability Press, Leeds, pp. 1-16.

Barnes, C. and Mercer, G. (1997), 'Breaking the Mould! An Introduction to Doing Disability Research', in C. Barnes, and G. Mercer (eds), Doing Disability Research, Disability Research Press, Leeds, pp. 1-14.

Barnes, C. and Oliver, M. (1995), 'Disability Rights: Rhetoric and Reality in the UK.' Disability and Society, Vol. 10(1), pp. 111-16.

Barton, L. (1989), Disability and Dependence, The Falmer Press, Lewes.

Barton, L. (1996), 'Sociology and Disability: Some Emerging Issues', in L. Barton (ed.), Disability and Society: Emerging Issues and Insights, Longman, London, pp. 3-17.

Barton, L. and Oliver, M. (1997), 'The Birth of Disability Studies', in L. Barton, and M. Oliver (eds), Disability Studies: Past, Present and Future, The Disability Press, Leeds, pp. 1-6. 
Begum, N. (1992), 'Disabled Women and the Feminist Agenda', Feminist Review Vol. 40, pp. 70-84.

Beresford, P. (1996), 'Poverty and Disable People: Challenging Dominant Debates and Policies', Disability and Society, Vol. 11(4), pp. 553-567.

Beresford, P. and Harding, T. (1990), 'Involving Services Users', NCVO News, October.

Berthoud, R. (1991), 'Meeting the Costs of Disability', in G. Dalley (ed.), Disability and Social Policy, Policy Studies Institute, London, pp. 64-100.

Berthoud, R., Lakey, J. and Mckay, S. (1993), The Economic Problems of Disabled People, Policy Studies Institute, London.

Berwin, C.R. Wing, J.K. Mangen, S.P. and Brugha, T.S. (1987), 'Principles and Practices of Measuring Needs in the Long Term Mentally Ill: The MRC Needs for Care Assessment', Psychological Medicine, Vol. 17(4), pp. 971-981.

Boyce, W. Broers, T. and Paterson J. (2001), 'CBR and Disability Indicators', Asia Pacific Disability Rehabilitation Journal Vol. 12(1), pp. 3-21.

Boyce, W. and Paterson, J. (2002), 'Community Based Rehabilitation for Children in Nepal', in M. Thomas, and M.J. Thomas (eds), Selected Readings in CBR - Series 2: Disability and Rehabilitation Issues in South Asia, National Printing Press, Bangalore, pp. 27-34.

Bradshaw, J. (1972), 'The Taxonomy of Social Needs', in G. McLachlan (ed.), Problems and Progress in Medical Care, Oxford University Press, Oxford, pp. 69-82.

Brian, L. and Layzell, S. (1994), Disabled in Britain: A World Apart, SCOPE, London.

Brown, R., Baine, D. and Neufeldt, A. (1996), 'Introduction', in R. Brown, D. Baine and A. Neufeldt (eds), Beyond Basic Care: Special Education and Community Rehabilitation in Low Income Countries, Captus Press, North York: ON, pp. 1-7.

Bryant, M. (1993), 'Religion and Disability: Some Notes on Religious Attitudes', in M. Nagler (ed.), Perspectives on Disability, 2nd ed., Health Market Research, Palo Alto: California, pp. 91-96.

Bunch, R. (1982), Two Ears of Corn: A Guide to People-Centered Agricultural Development, World Neighbors, Oklahoma City.

Burgdorf, R. (1980), The Legal Rights of Handicapped Persons: Cases, Materials and Text, Brooks, Baltimore.

Burgdorf, R. and Burgdorf, M. (1975), A History of Unequal Treatment: the Qualification of Handicapped Persons as a Suspect Class Under the Equal Protection Clause, Brooks, Baltimore.

Bury, M. (1982), 'Chronic Illness as Biographical Disruption' Sociology of Health and Illness, Vol. 4(2), pp. 167-192.

Bury, M. (1991), 'The Sociology of Chronic Illness: A Review of Research and Prospects', Sociology of Health and Illness, Vol. 13(4), pp. 451-468.

Bury, M. (1996), 'Defining and Researching Disability: Challenges and Responses' in C. Barnes, and G. Mercer (eds) Exploring the Divide: Illness and Disability, The Disability Press, Leeds, pp. 17-38.

Bynoe, I., Oliver, M. and Barnes, C. (1991), Equal Rights for Disabled People, Institute for Public Policy Research, London.

Calderbank, R. (2000), 'Abuse and Disabled People: Vulnerability or Social Difference', Disability and Society, Vol. 15(3), pp. 521-34.

Campbell, J. and Oliver, M. (1996), Disability Politics: Understanding Our Past, Changing Our Future, Routledge, London and New York.

Campling, J. (1981), Images of Ourselves: Women with Disabilities Talking, Routledge and Kegan Paul, London.

Carswell, R. (1998), Why Me? Approaches to the Problems of Suffering, OM Publishing, Cumbria. 
Chambers, R. (1983), Rural Development: Putting the Last First, Longman, Harlow.

Chambers, R. (1994a), 'The Origins and Practice of Participatory Rural Appraisal', World Development, Vol. 22(7), pp. 953-969.

Chambers, R. (1994b), 'Participatory Rural Appraisal (PRA): Analysis of Experience', World Development, Vol. 22(9), pp. 1253-1268.

Chambers, R. (1994c), 'Participatory Rural Appraisal (PRA): Challenges, Potentials and Paradigm", World Development, Vol. 22(10), pp. 1437-1454.

Chapuis, L., Flowers, J., Wirz, S., Jennings, B. and Jackson, K. (2000), 'Collaboration in Disability Policies - Collaboration Between Stakeholders of Disability in the South and in the North, International Journal of Rehabilitation Research, Vol. 23, pp. 81-89.

Chaudhury, G., Menon-Sen, K. and Zinkin, P. (1995), 'Disability Programmes in the community', in P. Zinkin, and H. McConachie (eds), Disabled Children and developing countries, Mac Keith Press, London, pp. 152-182.

Chimedza, R. (2001), 'The Impact of the Economic Structural Adjustment Programme on People with Disabilities in Zimbabwe', in P. Devlieger, and A. De Greve (eds), Disability and Poverty in North and South: Socio-political Factor and Gender Context, PHOS, Brussels, pp. 49-69.

Clapton, J. (1997), 'Disability, Inclusion and the Christian Churches: Practice, Paradox or Promise', Disability and Rehabilitation, Vol. 19(10), pp. 420-426.

Clayton, S. (1983), 'Social Needs Revisited', Journal of Social Policy, Vol. 12(2), pp. 215-34.

Coleridge, P. (1993), Disability, Liberation and Development, Oxfam, Oxford.

Coleridge, P. (2000), 'Disability and Culture', in M. Thomas, and M.J. Thomas (eds), Selected Readings in CBR - Series 1: CBR in Transition, National Printing Press, Bangalore, pp. 2-18.

Coleridge, P. (2002), 'Community Based Rehabilitation in a Complex Emergency: Study of Afghanistan', in M. Thomas, and M.J. Thomas (eds), Selected Readings in CBR Series 2: Disability and Rehabilitation Issues in South Asia, National Printing Press, Bangalore, pp. 35-49.

Cowan, J. (1979), A Dictionary to Modern Written Arabic (Arabic - English) Ott Harrassowitz, Wisebader.

Crow, L. (1992), 'Renewing the Social Model of Disability' Coalition, July Issue, pp. 5-9.

Crow, L. (1996), 'Including All of Our Lives: Renewing the Social Model of Disability', in C. Barnes, and G. Mercer (eds), Exploring the Divide: Illness and Disability, The Disability Press, Leeds, pp. 55-73.

CSCE (1992), The Helsinki Statement on Human Rights and Disabled People, The Cooperation and Society Conference of Europe (CSCE), Helsinki.

CSS (1998), Unemployment Among Jordanians, Centre for Strategic Studies (CSS), University of Jordan, Amman.

DAA (1999), 'Football Coach Dismissed for Comments about Disabled People' Disability Awareness in Action (DAA), Newsletter 70, March 1999.

DAA/UNISCO (1995), Overcoming Obstacles to the Integrating of Disabled People, Disability Awareness in Action (DAA), London.

Dalley, G. (1991), Disability and Social Policy, Policy Studies Institute, London.

Davis, K. (1986), Developing Our Own Definitions - Draft for Discussion, BCODP, London.

Davis, K. (1990), Activating the Social Model of Disability: The Emergence of the Seven Needs, Derbyshire Coalition of Disabled People, Derby.

De Greve, A. (2001), 'Disability as Diversity Factor Situated in the Framework of Sustainable Development', in P. Devlieger, and A. De Greve (eds), Disability and Poverty in North and South: Socio-political Factor and Gender Context, PHOS, Brussels, pp. 13-28. 
Despouy, L. (1991), Human Rights and Disability, United Nations Economic and Social Council, New York.

Despouy, L. (1993), Human Rights and Disabled Persons, United Nations Centre for Human Rights, Geneva.

Devlieger, P. (1999a), 'Frames of Reference in African Proverbs on Disabilities' International Journal of Disability, Education and Development, Vol. 46(4), pp. 439-51.

Devlieger, P. (1999b), 'From Handicap to Disability: Language Use and Cultural Meaning in United States', Disability and Rehabilitation, Vol. 21(7), pp. 346-354.

DFID (2000), Disability, Poverty and Development, Department for International Development, London.

Disability Alliance, (1987), Poverty and Disability, London.

Dossa, P. (1999), 'Towards a Methodology for Dis-Ability Research Among Ethno-cultural Minoroties', in B. Holzer, A. Vreede and G. Weigt (eds), Disability in Different Cultures: Reflections on Local Concepts and Beliefs about Disability in Different Cultures, Verlag Muhlerstrabe, Bielefeld, pp. 303-313.

Doyal, L. (1983), 'The Crippling Effects of Underdevelopment', in O. Shirley (ed.), Poverty and Disability in the Third World, Third World Group and AHRTAG, Fromme, pp. 7-14.

Doyal, N. and Gough, I. (1991), A Theory of Human Needs, Macmillan, Basingstoke.

Doyle, B. (1994), New Directions Towards Disabled Workers' Rights, Institute of Employment Rights, London.

Doyle, B. (1995), Disability Discrimination and Equal Opportunities: A Comparative Study of the Employment Rights of Disabled Persons, Mansell Ltd, London.

DPI (1982), Disabled People's International: Proceedings of the First World Congress, Singapore.

DPI (1992), Disabled People's International: Proceedings of the Third World Congress, Winnipeg.

Drake, R. (1994), 'The Exclusion of Disabled People from Positions of Power in British Voluntary Organisations', Disability and Society, Vol. 9(4), pp. 461-480.

Drake, R. (1996), 'A Critique of the Role of Traditional Charities', in L. Barton (ed.), Disability and Society: Emerging Issues and Insights, Longman, London, pp. 147-166.

DSS (1991), The Findings of Gulf Returnees Survey, Department of General Statistics, Amman.

DSS (1993), The Findings of Gulf Returnees Survey, Department of General Statistics, Amman.

ESCR (1976), International Covenant on Economic, Social and Cultural Rights (ESCR), UN, Geneva.

ESCWA (1989), Capabilities and Needs of Disabled Persons in the ESCWA Region, ESCWA, Amman.

ESCWA (1992), The Impact of Socio-Economic Changes on the Arab Family: Pilot Study, ESCWA, Amman.

ESCWA (1994), The Role of Family in Integrating Disabled Women into Society, ESCWA, Amman.

ESCWA (1995), Population Bulletin of the United Nations Economic Commission for Western Asia, ESCWA, Amman.

ESDP (1993), Economic and Social Development Plan: 1993-1997 (ESDP), Ministry of Planning, Amman.

Fawcett, C. (2000), Feminist Perspectives on Disability, Pearson Education Ltd, Edinburgh.

Fine, M. and Asch, A. (1990), 'Disability Beyond Stigma: Social Interaction, Discrimination, and Activism', in M. Nagler (ed.), Perspectives on Disability, Health Market Research, Palo Alto: CA, pp. 61-62. 
Finkelstein, V. (1980), Attitudes and Disabled People, World Rehabilitation Fund, New York.

Finkelstein, V. (1993), 'The Commonality of Disability', in J. Swain, V. Finkelstein S. French and M. Oliver (eds), Disabling Barriers - Enabling Environments, Sage, in association with the Open University, London, pp. 9-16.

Finkelstein, V. and Stuart, O. (1996), 'Developing New Services', in G. Hales (ed.), Beyond Disability: Towards an Enabling Society, Sage, London, pp. 170-187.

Florian, V. and Katz, S. (1983), 'The Impact of Cultural Ethnic and National Variables on Attitudes Towards the Disabled in Israel', International Journal of Intercultural Relations, Vol. 7, pp. 167-179.

Flowers, J. and Wirz, S. (2000), 'Rhetoric or Reality? The Participation of Disabled People in NGO Planning', Health Policy and Planning, Vol. 15(2), pp. 177-185.

Fox, N. (1993), Postmodernism, Sociology and Health, Open University Press, Buckingham.

Franklin, P. (1977), 'Impact of Disability on the Family Structure', Social Security Bulletin, Vol. 40(5), pp. 3-18.

French, S. (1993), 'Disability, Impairment or Something In-Between?' in J. Swain, V. Finkelstein S. French and M. Oliver (eds), Disabling Barriers - Enabling Environments, Sage, in association with the Open University, London, pp. 17-25.

French, S. (1994), Institutional and Community Living: On Equal Terms; Working with Disabled People, Butterworth-Heinman, Oxford.

Gadacz, R. (1994), Re-thinking Disability: New Structure, New Relationships, The University of Alberta Press, Edmonton.

Gain, S. and Abdulwahab, S. (2000), 'Issues and Obstacles in Disability Research in Saudi Arabia', Asia Pacific Disability Rehabilitation Journal, Vol. 13(1), pp. 45-49.

Gal, J. and Bar, M. (2000), 'The Needed and the Needy: The Policy Legacies of Benefits for Disabled War Veterans in Israel', International Social Policy, Vol. 29(4), pp. 577-598.

Garland, G. (1994), The Eye of the Beholder: Deformity and Disability in the Graceo-Roman World, Cornell University Press, New York.

Gaventa, W. (2002), 'Defining and Assessing Spirituality and Spiritual Supports: A Rationale for Inclusion in Theory and Practice', in W. Gaventa and D. Coulter (eds), Spirituality and Intellectual Disability: International Perspectives in the Effect of Culture and Religion on Healing Body, Mind and Soul, The Haworth Press, New York, pp. 29-48.

Ghai, A. (2001), 'Marginalization of Disability: Experiences from the Third World', in M. Priestley (ed.), Disability and Life Course: Global Perspectives, Cambridge University Press, Cambridge, pp. 26-37.

Glendinning, C. (1991), 'Losing Ground: Social Policy of Disabled People in Great Britain', Disability, Handicap and Society, Vol. 6(1), pp. 3-20.

Goffman, E. (1961), Asylum: Essays on the Social Situation of Mental Patients and Other Inmates, Penguin, Harmondsworth.

Goffman, E. (1963), Stigma, Notes on the Management of Spoiled Identity, Penguin, Harmondsworth.

Gregory, R. (1997), 'Definition as Power', Disability and Rehabilitation, Vol. 19(11), pp. 487-489.

Groce, N. (1999), 'General Issues in Research on Local Concepts and Beliefs about Disability', in B. Holzer, A. Vreede and G. Weigt (eds), Disability in Different Cultures: Reflections on Local Concepts and Beliefs about Disability in Different Cultures, Verlag Muhlerstrabe, Bielefeld, pp. 285-290.

GUVS (1994), The Annual Report of The General Union of Voluntary Societies (GUVS), Co-operative Society for Press Workers, Amman. 
Habibi, L. (1998), Gender and Disability: Women's Experience in the Middle East, Oxfam UK and Ireland, Oxford.

Haj, F. (1970), Disability in Antiquity, Philosophical Library, New York.

HALS (1990) Health and Activity Limitations Survey: Highlights, Disabled Persons in Canada, Canada Statistics, Ottawa.

Hamerman, S. and Maikowski, S. (1981), The Economics of Disability: International Perspectives, Rehabilitation International, UN, New York.

Hannum, H. (1994), Human Rights and the Deaf: The Deaf Way Perspective for International Conference on Deaf Culture, Gullandat University, Washington D C.

Harris-White, B. (1996), The Political Economy of Disability and Development: With Special Reference to India, United Nations Research Institute, Geneva.

Harrison, T. (1995), Disability Rights and Wrongs, Lion Publishing, Oxford.

Hartley, S. (2001), "Commentary on 'Community Based Service Delivery in Rehabilitation:

The Promise and the Paradox' by Kendal, Buys and Lamer", Disability and Rehabilitation, Vol. 23(1), pp. 25-29.

Hastie, R. (1997), Disabled Children in a Society at War: a Casebook from Bosnia, Oxfam, Oxford.

Heimlier, E. (1967), Mental Illness and Social Work, Penguin Books, London.

Helander, E. (1993), Prejudice and Dignity: An Introduction to Community-Based Rehabilitation, UNDP, New York.

Helander, E. (2000), '25 years of Community-based Rehabilitation', Asia Pacific Disability Rehabilitation Journal, Vol. 11(1), pp. 4-8.

Helander, E., Mendis, P., Nelson, G. and Geordt, A. (1989), Training in the Community for People with Disabilities, WHO, Geneva.

Hilali, M. and Khan, M. (1996), Interpretation of the Meaning of the Noble Qur'an in the English Language, Dar-Es-Salam Publication, Riyadh.

Hillyer, B, (1993), Feminist and Disability, University of Oklahoma Press, Norman.

Hinchcliffe, A. (1994), Explanatory Report on the Situation of Disability in Jordan, Mission Report for Disability Development Action (DDA), London.

Hinchcliffe, A. (2002), Children with Cerebral Palsy in Developing Countries: A Manual for Therapists and Community Workers, Intermediate Technology, London.

Hirst, M. and Baldwin, S. (1994), Unequal Opportunities. Growing up Disabled, Social Policy Research Unit, York.

Hisham, A.M. (1955), The Life of Mohammed, Oxford University Press, Oxford.

HLID (1994), The Annual Report of the Holy Land Institute for the Deaf, Salt.

Hoddle, G. (1999), 'What I Really Believe', An Interview by H. Harris, Daily Mirror, 2 February 1999.

Hunt, P. (1966) 'A Critical Condition', in P. Hunt (ed.), Stigma: The Experience of Disability, Geoffrey Chapman, London, pp. 145-164.

ILO (1994), Assessment of Business Skills Training and Loans for Disabled MicroEntrepreneurs in Kenya, Geneva.

ILO (1995), The Framework of ILO Action Against Poverty: the Policy Agenda and ILO, International Institute of Labour Studies, Geneva.

ILO, UNESCO, WHO (1994), CBR for and with People with Disabilities, WHO, ILO, UNESCO, Geneva.

Inclusion Intemational (1996), Promoting and Ensuring Human Dignity and Human Rights: Response to the IBC Preliminary Draft of a Universal Declaration of March 1996 on Human Genome and Human Rights, Roeher, Institute, North York, ON. 
Ingstad, B. (1995), 'Mpho Ya Modimo - A Gift from God: Perspectives on Attitudes Towards Disabled People', in B. Ingstad, and S. Whyte (eds), Disability and Culture, University of California Press, Berkley, pp. 246-265.

Ingstad, B. and Whyte, S. (1995), 'Disability and Culture: An Overview', in B. Ingstad, and S. Whyte (eds), Disability and Culture, University of California Press, Berkley, pp. 332.

Iyanar, J. (2001), 'Listening to Different Voices - Inclusion and Exclusion of People with Disabilities in Education', Asia Pacific Disability Rehabilitation Journal, Vol. 12(2), pp. 155-159.

IYDP (1981), 'The International Year of Disabled Persons', in Compendium of Declarations on the Rights of Disabled Persons, United Nations, New York.

Jackson, H. (1988), 'Approaches to Rehabilitation of People with Disabilities: A Review', Journal of Social Development in Africa, Vol. 3(1), pp. 39-53.

Jane, R. and Hanks, L. Jr. (1948), 'The Physically Handicapped in Certain Non-Occidental Societies', Journal of Social Issues, Vol. 42, pp. 11-20.

Jaques, M. (1973), 'Reactions to Disabilities in China: A Comparative, Structural and Descriptive Analysis', Rehabilitation Coursel Bull, Vol. 17, pp. 206-217.

Jayasooria, D., Krishnan, B. and Ooi, G. (1997), 'Disabled People in a Newly Industrialised Economy: Opportunities and Challenges in Malaysia', Disability and Society, Vol. 12(3), pp. 455-463.

Johnson, R. (1991), 'The Health Transition: The Cultural Inflation of Morbidity During the Decline of Mortality', Health Transition Review, Vol. 1(1), pp. 39-68.

Jones, K. and Fowles, A. (1984), Ideas on Institutions, Routledge and Kegan Paul, London.

JSMA (1991), Community Based Rehabilitation: Proceedings of the Third Seminar of Jordanian Swedish Medical Association (JSMA), Amman.

Kandil, A. (1992), The Role of Mass Media and Public Awareness of Disability, ESCWA, Amman.

Kasnitz, D. (2001), 'Life Event Histories and the US Independent Living Movement', in M. Priestley (ed.), Disability and Life Course: Global Perspectives, Cambridge University Press, Cambridge, pp. 67-78.

Kasnitz, D. and Shuttleworth, R. (2001), 'Anthropology and Disability Studies', in L. Rogers, and B. Swadner (eds), Semiotics and Disability: Integrating Categories of Difference, State of York Press, Albany, pp. 67-78.

Khan, M. (1979), The Translation of the Meaning of the Sahih Al Bukhari (Arabic-English), Vol. VII, Kazi, Chicago.

Khan, M., Anker, M., Patel, C., Barge, S., Sadwani, H. and Khole, R. (1991), 'The Use of Focus Groups in Social and Behavioral Research: Some Methodological Issues', World Health Statistics Quarterly, Vol. 44(3), pp. 145-9.

Khatib, A. (1989) 'Disability Situation in Jordan', Working Paper Presented at ESCWA Seminar: Capabilities and Needs of Disabled Persons in the ESCWA Region, ESCWA, Amman.

Kheraigi, F. (1990), Special Education Development in the Kingdom of Saudi Arabia from 1958-1987, Unpublished Doctorate Dissertation.

Khoury, N. and Maghadam, M. (1995), Gender and Development in the Arab World: Women's Economic Participation, Zed Books, London.

Khoury, S. and Massad, J. (1992), 'Consanguineous Marriage in Jordan', American Journal of Medical Genetics, 43(5), pp. 769-75.

Kingston, P. (1996), Britain and the Politics of Modernization in the Middle East - 19451958, Cambridge Press, Cambridge.

Kirk, S. (1989), Educating Exceptional Children, Houghton Mifflin, Boston. 
Kitchen, R. (2000), 'The Researcher Opinions on Research: Disabled People and Disability Research', Disability and Society, Vol. 15(1), pp. 25-47.

Krefting, L. and Krefting D. (2002), 'Community Approaches to Handicap in Development

(CAHD): The Next Generation of CBR Programmes', in M. Thomas, and M.J. Thomas (eds), Selected Readings in CBR, Series 2 -Disability and Rehabilitation in South Asia, National Printing Press, Bangalore, pp. 100-110.

Lacey, R. (1988), 'Human Needs and Human Rights', Community Care, Vol. 690, pp. 20-21. Lang, R. (2000), 'The Role of NGO's in the Process of Empowerment and Social Transformation of People with Disabilities', in M. Thomas, and M.J. Thomas (eds), Selected Readings in CBR, Series 1: CBR in Transition, National Printing Press, Bangalore, pp. 21-38.

Langan, M. (1998), Welfare: Needs, Rights and Risks, Routledge, London.

Lansdown, G. (2001), It is our World too: A Report on the Lives of Disabled Children, Disability Awareness in Action, London.

Larsen, K. (2000), From Charity Towards Inclusion: the way Forward for Disability Support through Danish NGOs, Ministry of Foreign Affairs, Copenhagen.

Liu, W. (1998), Elder Care Policies in China: The Social Value Foundation is in the Family, East Asian Institute and Singapore University Press, Singapore.

Llewellyn, A. and Hogan, K. (2000), 'The Use and Abuse of Models of Disability', Disability and Society, Vol. 15(1), pp. 157-165.

Lonsdale, S. and Walker, A. (1984), A Right to Work: Disability and Employment, Disability Alliance and Low Pay Unit, London.

Lunt, N. and Thornton, P. (1993), Employment Policies for Disabled People: A Review of Legislation and Services in Fifteen Countries, ED Research Series No 16, Sheffield Employment Department.

Lunt, N. and Thornton, P. (1994), 'Disability and Employment: Towards an Understanding of Discourse and Policy', Disability and Society, Vol. 9(2), pp. 223-238.

Magi, M. and Allander, E. (1981), 'Towards A Theory of Perceived and Medically Defined Needs', Sociology of Health and Illness, Vol. 3(1), pp. 49-71.

Mallory, B. (1993), 'Changing Beliefs About Disability in Developing Countries: Historical Factors and Sociocultural Variables', in B. Mallory, R. Nicholls, J. Charlton and K. Marfo (eds), Traditional and Changing Views of Disability in Developing Societies: Causes, Consequences, and Cautions, World Rehabilitation Fund IEEIR, University of New Hampshire, Monograph No 53.

Marks, D. (1997a), 'Models of Disability', Disability and Rehabilitation, Vol. 19(3), pp. 85-91.

Marks, D. (1997b), 'Who Needs Models?', Disability and Rehabilitation, Vol. 19(11), pp. $492-495$.

Marsouq, H. (1980), A Facet Theory and Analysis of Attitudes Towards Handicapped Individuals in Saudi Arabia, Unpublished Doctorate Dissertation.

Martin, J., Meltzer, H. and Elliot, D. (1988), OPCS Surveys of Disability in Great Britain: The Prevalence of Disability Among Adults, HMSO, London.

Martin, J. and White, A. (1988), OPCS Surveys of Disability in Great Britain: The Financial Circumstances of Disabled Adults in Private Households, HMSO, London.

Martin, J., White, A. and Meltzer, H. (1989), OPCS Surveys of Disability in Great Britain Disabled Adults: Services, Transport and Employment, HMSO, London.

Maslow, A. (1970), Motivation and Personality, Harper Brothers, New York.

McConachie, H. and Zinkin, P. (1995), 'Conclusions', in P. Zinkin, and H. McConachie (eds), Disabled Children and Developing Countries, Mac Keith Press, London, pp. 219-234. 
McGaha, C. (2000), 'Development of Parenting Skills in Individuals with an Intellectual Impairment: An Epigenetic Explanation', Disability and Society, Vol. 17(1), pp. 81-90.

McLaughlan, R. and Partridge, T. (1997), The Life of Christ: 360 Daily Readings, CWR, Surrey.

ME (1996) The Statistical Yearbook, The Ministry of Education (ME), Amman.

Medawar, C. (1983), 'The Disabled Consumer: How Multinational Corporations Affected the Third World', in $\mathrm{O}$. Shirley (ed.) A Cry for Health: Poverty and Disability in the Third World, Third World Group and AHRTAG, Fromme, pp. 73-78.

Melville, B. (1993), 'Rapid Rural Appraisal: Its Role in Health Planning in Developing Countries', Tropical Doctor, Vol. 23, pp. 55-58.

Mercer, G. and Barnes, C. (1995), 'Disability: Emancipation, Community Participation and Disabled People', in M. Magi, and G. Graig (eds), Community Empowerment: A Reader in Participation and Development, London, Zed Books, pp. 45-59.

Metts, R. and Metts, N. (2000), 'Official Development Assistance to Disabled People in Ghana', Disability and Society, Vol. 15(3), pp. 475-488.

Mezerville, G. (1979), Disability and Rehabilitation in Rural Costa Rica, University Centre for International Rehabilitation, East Lansing.

Miles, M. (1994), 'Disability Care and Education in 19th Century India: Some Dates, Places and Documentation', Supplement to Action Aid Disability News, 5 (2) pp. 2-22.

Miles, M. (1995), 'Disability in an Eastern Religious Context: Historical Perspectives', Disability and Society, Vo. 10(1), pp. 49-69.

Miles, M. (1999), 'Disability on Different Models: Glimpses of an Asian Heritage', Disability and Society, Vol. 15(4), pp. 603-618.

Miles, S. (1996), 'Engaging with the Disability Rights Movement: the Experience of Community Based Rehabilitation in Southern Africa', Disability and Society, Vol. 11(4), pp. 501-17.

Morris, J. (1991), Pride Against Prejudice: Transforming Attitudes to Disability, The Women's Press Ltd, London.

Morris, J. (1992), 'Personal and Political: a Feminist Perspective on Researching Physical Disability,' Disability, Handicap and Society, Vol. 7(2), pp. 157-66.

Morris, J. (1993), Independent Lives, Community Care and Disabled People, Macmillan, Basingstoke.

Morris, J. (1996), Encounters with Strangers: Feminism and Disability, The Women's Press, London.

MSD (1987), Poverty Survey, Ministry of Social Development (MSD) and Jordan Press Foundation, Amman.

MSD (1989), The Annual Report of Ministry of Social Development, Jordan Press Foundation, Amman.

MSD (1994), The Annual Report of Ministry of Social Development, Jordan Press Foundation, Amman.

MSD (1996), The Annual Report of Ministry of Social Development, Jordan Press Foundation, Amman.

Muller, D. (2001), 'Editorial Introduction: Community Based Rehabilitation: The Promise and the Paradox', Disability and Rehabilitation, Vol. 23(1), pp. 15.

Murray, S.A. Tapson, J. Tunnbul, L. McCallum, J. and Little, A. (1994), 'Listening to Local Voices: Adapting Rapid Appraisal to Assess Health and Social Needs', British Management Journal, Vol. 308(12), pp. 689-700.

NCWDP (1993), Law for Welfare of Disabled People No 12 for the Year 1993, The Jordan Printing Press, Amman. 
NCWDP (1994), The National Council for the Welfare of Disabled People, Jordan Press Foundation, Amman.

Neufeldt, A. and Albright, A. (1998), 'Economic Integration: The Challenge', in A. Neufeldt, and A. Albright (eds), Disability and Self-directed Employment: Business Development Model, Captus Press Inc, York University Campus.

Nichols, P. (1991), Social Survey Methods, Oxfam Publication, London.

NKJV (1985), The Holy Bible, New King James Version, Thomas Nelson Publishers, Nashville.

Oliver, M. (1990), The Politics of Disablement, Macmillan, Basingstoke.

Oliver, M. (1992), 'Changing the Social Relations of Research Production', Disability, Handicap and Society, Vol. 7 (2), pp. 101-14.

Oliver, M. (1995), 'Disability, Empowerment and The Inclusive Society', in G. Zarb (ed.), Removing Disabling Barriers, Policy Studies Institutes, London, pp. 17-26.

Oliver, M. (1996), Understanding Disability: From Theory to Practice, Macmillan, Basingstoke.

Oliver, M. (1997), 'Emanicipatory Research: Realistic Goal or Impossible Dream?', in C. Barnes, and G. Mercer (eds), Doing Disability Research, The Disability Press, Leeds, pp. 15-31.

Oliver, M. and Barnes, C. (1997), 'All We Say is Give Disabled People a Chance', Disability and Society, Vol. 12(5), pp. 221-240.

Oliver, M. and Barnes, C. (1998), Disabled People and Social Policy: From Exclusion to Inclusion, Longman, London.

Oliver, M. and Sapey, S. (1999), Social Work with Disabled People, Macmillan, Basingstoke.

Ong, B. Humphris, G. Amett, H. and Rifkan, S. (1991), 'Rapid Appraisal in an Urban Setting: An Example from Developed World', Social Science in Medicine, Vol. 32(8), pp. 909-915.

OPCS2 (1989), The Financial Circumstances of Disabled People, RADAR, London.

Parsons, T. (1951), The Social System, Free Press, New York.

Peat, M. (1997), Community Based Rehabilitation, Saunders, London.

Pell, S. (1997), 'Relationship Between Use of Technology and Employment Rates for People with Physical Disabilities in Australia: Implications for Education and Training Programmes', Disability and Rehabilitation, Vol. 19(8), pp. 332-338.

Pfeiffer, D. (1998), 'The ICIDH and the Needs for its Revision', Disability and Society, Vol. 13(4), pp. 503-524.

Pfeiffer, D. (1999), 'The Problem of Disability Definition: Again', Disability and Rehabilitation, Vol. 21(8), pp. $392-395$.

Pfeiffer, D. (2000), "The Devils Are in the Details: The ICIDH2 and the Disability Movement', Disability and Society, Vol. 15(1), pp. 1079-82.

Pfeiffer, D. (2001), 'The Paradox of Changing the Service Delivery System in the Field of Rehabilitation', Disability and Rehabilitation, Vol. 23(1), pp. 16-17.

Pinder, R. (1995), 'Bringing Back the Body Without the Blame: the Experience of Ill and Disabled People at Work', Sociology of Health and Illness, Vol. 17(5), pp. 605-631.

Pinder, R. (1996), 'Sick - but Fit or Fit - but Sick? Ambiguity and Identity at the Workplace', in C. Barnes, and G. Mercer (eds), Exploring the Divide: Illness and Disability, Disability Press, Leeds, pp. 135-156.

Potts, M. and Fido, R. (1991), A Fit Person to be Rewarded: Personal Account of Life in Mental Deficiency Institution, Northgate House, Plymouth.

Pratt, P. and Loizos, P. (1992), Choosing Research Methods, Oxfam Publication, London. 
Priestley, M. (1997), 'Whose Research? A Personal Audit', in C. Barnes, and G. Mercer (eds), Doing Disability Research, Disability Press, Leeds, pp. 88-107.

Priestley, M. (1998), 'Construction and Creation: Idealism, Materialism and Disability Theory', Disability and Society, Vol. 13(1), pp. 75-94.

Priestley, M. (2001), 'Introduction: The Global Context of Disability', in M. Priestley (ed.), Disability and the Life Course: The Global Context, Cambridge University Press, Cambridge, pp. 3-14.

Prescott-Clarck, P. (1990), Employment and Handicap, Social and Community Planning Research, London.

Pupulin, E. (1993), 'The Past Decade Around the World', CBR News, Vol. 15, pp. 6-7.

QAF (1979), National Survey of the Handicapped in Jordan, The Queen Alia Fund and Jordan Press Foundation, Amman.

QAF (1994), The Annual Report of Queen Alia Fund, Jordan Press Foundation, Amman.

Quigley, P. and Ebrahim, G. (1994), 'Women and Community Health Workers Promoting Health and Development', Journal of Tropical Paediatrician, Vol. 40, pp. 66-71.

Quryouti, Y. (1984), Special Education in Jordan: A Present Status of Needs Assessment Study, Unpublished Doctorate Dissertation.

Rachman, P. and Grant, G. (1994), 'Setting One Agenda for Empowering Persons with Advantages within the Research Process', In M. Rioux, and B. Bach (eds), Disability Is Not Measles: New Research Paradigms in Disability, L'Instituitut Roeher, North York: ON, pp. 227-244.

Racino, J.A. (1999), 'Qualitative Evaluation and Research: Towards Community Support for All', in A.J. Racino (ed.), Policy Programme Evaluation, and Research in Disability: Community Support for All, The Haworth Press, New York, pp. 3-21.

Rasmussen, S. (1989), 'Accounting for Belief: Causation, Misfortune, and Evil in Tuareq System of Thoughts', Man, Vol. 24, pp. 24-144.

Rieser, R. and Mason, M. (1990), Disability Equality in the Classroom: A Human Rights Issue, Inner London Education Authority, London.

Rioux, M. (1994), 'New Research Directions and Paradigms: Disability Is Not Measles', in M. Rioux, and M. Bach (eds), Disability Is Not Measles, L'Instituitut Roeher, North York: ON, pp. 1-18.

Rock, P. (1981), 'The Extra and Hidden Cost of Disability', in J. Campling (ed.), The Handicapped Person: A New Perspective for Social Workers?, RADAR, London.

Rock, P. (1996), 'Eugenics and Euthanasia: A Cause for Concern for Disabled People, Particularly Disabled Women', Disability and Society, Vol. 11(1), pp. 121-27.

Roeher Institute (1995), Harm's Way - The Many Faces of Violence and Abuse Against Persons with Disabilities, North York: ON.

Rose, A. (1997), 'Who Cause the Blind to See: Disability and Quality of Religious Life', Disability and Society, Vol. 12(3), pp. 381-394.

Rudra, A. (1995), 'The Basic Needs Concept and its Implementation in Indian Development Planning', in J. Cameron (ed.), Poverty and Power: the Role of Institution and the Market in Development, Oxford University Press, Oxford, pp. 3-14.

Ryan, J. and Thomas, F. (1987), The Politics of Mental Handicap, Penguin, Harmondsworth. Saadawi, N. (1980), The Hidden Face of Eve: Women in the Arab World, Zed Books, London.

Safford, P. (1978), Teaching Young Children With Special Needs, CV. Masher Company, Saint Louis.

Said, E. (1994), Culture and Imperialism, Atlas, Amsterdam. 
Savolainen, H. Kokkala, H. and Alasuutari, H. (2000), Meeting Special and Diverse Educational Needs: Making Inclusive Education a Reality, Ministry for Foreign Affairs of Finland, Helsinki.

SCOP (1994), Disabled in Britain, London.

Scotch, R. (1990), 'Disability As the Basis for a Social Movement: Advocacy and the Politics of Definition', in M. Nagler (ed.), Perspectives on Disability, Health Market Research, Palo Alto: CA, pp. 238-248.

Scrimshaw, and Hurtado, E. (1987), Rapid Assessment Procedures for Nutrition and Primary Health Care, UCLA Press, Los Angles.

Sen, K. (1995), 'Gender Culture and Later Life: A Dilemma for Contemporary Feminism', Gender and Disability, Vol. 3(3), pp. 36-42.

Sentumbwe, N. (1995), 'Sighted Lovers and Blind Husbands: Experiences of Blind Women in Uganda', in B. Ingstad, and S. Whyte (eds), Disability and Culture, University of California Press, Berkeley, pp. 159-173.

Shakespeare, T. (1994), 'Cultural Representation of Disabled People: Dustbin for Disavowal?' Disability and Society, Vol. 9(3), pp. 283-299.

Shakespeare, 'T. (1996), 'Disability, Identity, Difference', in C. Barnes, and G. Mercer (eds), Exploring the Divide: Illness and Disability, The Disability Press, Leeds, pp. 94-113.

Shang, X. (2000), 'Bridging the Gap Between Planned and Market Economies: Employment Policies for People with Disabilities in Two Chinese Cities', Disability and Society, Vol. 15(1), pp. 135-156.

Shearar, A. (1981), Disability, Whose Handicap? Blackwell, Oxford.

Sime, J. (1992), Socio-Economic Profile of Social Changes in Jordan: Social Actors in Transition With a Focus on Women, Unpublished Masters Dissertation.

Sobsey, D. (1994), Violence and Abuse in the Lives of People with Disabilities: The End of Silent Acceptance, Paul, H. Brookes, Baltimore.

Stewart, F. (1989), 'Basic Needs Strategies, Human Rights, and the Rights to Development', Human Rights Quarterly, Vol. 11, pp. 347-374.

Stiker, H-J. (1999), A History of Disability, The University of Michigan Press, Ann Arber.

Stone, D.A. (1985), The Disabled State, Macmillan, London.

Stone, E. (1996), 'A Law to Protect a Law to Prevent: Contextualising Disability Legislation in China', Disability and Society, Vol. 11(4), pp. 469-484.

Stone, E. (1999), 'Disability and Development in the Majority World', in E. Stone (ed.), Disability and Development: Learning from Action and Research on Disability in the Majority World, The Disability Press, Leeds, pp. 1-18.

Stone, E. and Priestley, M. (1996), 'Parasites, Pawns and Partners: Disability Research and the Role of Non-Disabled Researchers', British Journal of Sociology, Vol. 47(4), pp. 699-716.

Swannell, J. (1994), The Oxford Dictionary (ed), Clarendon Press, Oxford.

Tennant, A. (1997), 'Models of Disability: A Critical Perspective', Disability and Rehabilitation, Vol. 19(11), pp. 478-479.

Thayer, R. (1973), 'Measuring Needs in the Social Services', Social and Economic Admin, Vol. 7, pp. 91-105.

The Economist (1999), 'After King Hussein', 13-19 February, 1999, pp. 124.

Thies, J. and Grady, H. (1991), Participatory Rapid Appraisal for Community Development: A Training Manual Based on Experience in Middle East and North Africa, IIED, London.

Thomas, A., Bax, M. and Smyth, D. (1989), The Health and Social Needs for Young Adults with Physical Disabilities, Blackwell Scientific Publications, Oxford. 
Thomas, C. (1999), Female Forms: Experiencing and Understanding Disability, Open University Press, Buckingham.

Thomas, D. (1982), The Experience of Handicap, Methuen, London.

Thomas, M. (2000), 'Feasibility of Integrating People with Disabilities in Savings and Credit Programmes in Bangladesh', Asia Pacific Disability Rehabilitation Journal, Vol. 11(1), pp. 27-31.

Thomas, M., Hema, N.S., Raja, S. and Prakash, S. (2001), 'Women with Disabilities in South Asia', Women in Action, Vol. 2, pp. 13-17.

Thomas, M. and Thomas, M.J. (2001), 'Planning for Community Participation in CBR', Asia Pacific Disability Rehabilitation Journal, Vol. 12(1), pp. 44-51.

Thornton, P. (1998), Employment Quotas and National Rehabilitation Fund for Persons with Disabilities, Rehabilitation Branch of ILO, Geneva.

Thornton, P. and Lunt, N. (1995), Employment for Disabled People, Social Obligation or Individual Responsibility, Social Policy Research Unit, York.

Thomton, P. and Lunt, N. (1997), Employment Policies for Disabled People in Eighteen Countries: A Review, Social Policy Research Unit, York.

Tilstone, C. and Visser, J. (1998), 'Learning Difficulties', in V. Varma (ed.), Coping with Children in Stress, Ashgate, Aldershot, pp. 1-19.

Topliss, E. (1982), Social Responses to Handicap, Longman, Hatlow.

Treloar, L. (1999), 'Spiritual Beliefs and Response to Disability and the Church', Journal of Religion, Disability and Health, Vol. 3(4), pp. 5-32.

Trieschmann, R.B. (1980), Spinal Cord Injuries: Psychological, Social and Vocational Adjustment, Pergamon Press, Oxford.

Turmusani, M. (1994), Mental Retardation in Special Education Centres in Jordan: National Survey, Unpublished Masters Dissertation.

Turmusani, M. (1999), 'The Economic Needs of Disabled People in Jordan: from the Personal to the Political Perspective', Disability Studies Quarterly, Vol. 19 (1), pp. 32-42.

Turmusani, M. (2001), 'Disabled Women in Islam: Middle Eastern Perspective', Religion, Health and Disability, Vol. 5(2/3), pp. 73-85.

Turmusani, M. (2001), 'Work and Adulthood: Economic Survival in the Majority World', in M. Priestley (ed.) Disability and Life Course: Global Perspectives, Cambridge University Press, Cambridge, pp. 192-205.

Turmusani, M. (2002), 'Disability and Development in Kosovo: The Case for CBR Approach', Asia Pacific Disability and Rehabilitation Journal, Vol. 13(1), pp. 19-28.

Turmusani, M. and Sime, E. (1994), Evaluation Report on the Disability Provision in Jordan, GUVS, Amman.

Turmusani, M. Vreede, A. and Wirz, S. (2002), 'Some Ethical Issues in CBR in Developing Countries', Disability and Rehabilitation, Vol. 24(10), pp. 558-564.

Twible, R. and Henley, E. (1993), 'A Curriculum Model for a Community Development Approach to Community Based Rehabilitation', Disability and Society, Vol. 8(1), pp. 43-57.

UN (1948), The Universal Declaration of Human Rights, New York.

UN (1948), The Universal Declaration of Human Rights: Article 25 Adopted by the General Assembly Resolution 217 A (III) of 10 December, New York.

UN (1992), The Universal Declaration of Human Rights, New York.

UN (1993), Demographic Yearbook: Special Issue on Population, Ageing and the Situation of Elderly Disabled Persons, United Nations Department of Social Information and Policy, New York.

UN (1994), The Standard Roles on the Equalisation of Opportunities for Persons with Disabilities, New York. 
UN (1995), Hidden Sisters: Women and Girls with Disabilities in the Asian and Pacific Region, Economic and Social Commission for Asia and the Pacific (ESCAP), New York.

UN (1996), Report of the Special Rapporteur on Monitoring the Implementation of the Standard Rules on Equalization of Opportunities for Persons with Disabilities, Commission for Social Development, New York.

UNESCO (1988), Review of the Present Situation of Special Education, UNESCO, Paris.

UNESCO (1994), The Salamanca Statement and Framework for Action on Special Needs Education, ED-94/WS/18, UNESCO, Paris.

UNESCO (1996), Legislation Pertaining to Special Needs Education, UNESCO, Paris.

UNICEF (1989), The State of the World Children, Oxford University Press, New York.

UNICEF (1991), Jordanian Children in the Eye of the Storm, UNECIF Regional Office, Amman.

UNICEF (1993), Priorities for Childhood Disability Program in Jordan, UNECIF Regional Office, Amman.

UNICEF (1998), The State of the World Children, Oxford University Press, New York.

UNHCR (1996), Assisting Disabled Refugees: A Community Based Approach, UNHCR, Geneva.

UPIAS (1976), Fundamental Principles of Disability, Union of the Physically Impaired Against Segregation (UPIAS), London.

Walker, A. (1982), Unqualified and Underemployed: Handicapped Young People and the Labour Market, Macmillan, Basingstoke.

Walker, A. (1988), Consumer Survey on the Needs of People of Spinal Cord Injury, Unpublished Masters Dissertation.

Walker, L. and Walker, A. (1991), 'Disability and Financial Need - The Failure of the Social Security System', in G. Dalley (ed.) Disabling and Social Policy London, Policy Studies Institute, London, pp. 20-56.

Wendall, S. (1996), The Rejected Body: Feminist Philosophical Reflections on Disability, Routledge, London.

Werner, D. (1987), Disabled Village Children: A Guide for Community Health Workers, Rehabilitation Workers and Families, Hesperian Foundation, Palo Alto: CA.

Werner, D. (1995), 'Strengthening the Role of Disabled People in CBR Programmes', in B. O'Toole, and R. MacConeky (eds), Innovations in Developing Countries for People with Disability, Hull Publications, Hull, pp. 15-28.

Werner, D. (1998), Nothing About Us Without Us: Developing Innovative Technologies For, By and With Disabled Persons, Health Wrights, Palo Alto: CA.

Westbrook, M.T. Legge, V. and Pennay, M. (1993), 'Attitudes Towards Disability in Multicultural Society', Social Science and Medicine, Vol. 36(5), pp. 615-623.

Westmacott, K, and Westmacott, J. (1995), 'Designing and Simple Technologies in CBR', NU News on Health Care in Developing Countries, Vol. 9(2), pp. 4-7.

Wetherly, P. (1996), 'Basic Needs and Social Policies', Critical Social Policy, Vol. 16(46), pp. 45-63.

WHO (1980), International Classification of Impairments, Disabilities and Handicaps, World Health Organisation, Geneva.

WHO (1989), Disability Prevention and Rehabilitation, World Health Organisation, Geneva. Wilkinson, G. and Pelosi, A. (1989), 'Economic Appraisal', in G. Wilkinson, and A. Pelosi (eds), The Scope of Epidemiological Psychiatry: Essays in Honour of Michael Shepherd, Taylor and Francis in association with Routledge, Florence: KY, pp. 63-73.

Williams, G. (1991), 'Disablement and the Ideological Crisis in Health Care', Social Science and Medicine, Vol. 32, pp. 517-24. 
Williams, G. (1991), 'Disablement and the Ideological Crisis in Health Care', Social Science and Medicine, Vol. 32, pp. 517-24.

Williams, G. (1996), 'Representing Disability: Some Questions of Phenomenology and Politics' in C. Barnes, and G. Mercer (eds), Exploring the Divide: Illness and Disability, The Disability Press, Leeds, pp. 194-212.

Williams, L. (1995), 'Rights Not Charity', in P. Zinkin, and H. McConachie (eds), Disabled Children and Developing Countries, Mac Keith Press, London, pp. 214-218.

Wilson, R. (1991), Politics and Economy of Jordan, SOAS, London.

Wiman, R. (1996), The Disability Dimension in Development Action: Manual on Inclusive Planning, United Nations and National Research and Development Centre for Welfare and Health, Helsinki.

Wood, P. (1981), International Classification of Impairment, Disability, and Handicap, WHO Geneva.

WPACDP (1983), The World of Action Concerning Disabled People: Rehabilitation and Employment Convention number 169, United Nations, Geneva.

Zarb, G. (1992), 'On the Road to Damascus: First Step Towards Changing the Relation of Research Production', Disability, Handicap and Society, Vol. 7(2), pp. 125-38.

Zola, I. (1989), 'Towards a Necessary Universalizing of Disability Policy', Millbank Memorial Quarterly, Vol. 67(2), pp. 401-28.

Zola, I. (1993), 'Disability Statistics, What We Count and What it Tells Us: A Personal and Political Analysis', Journal of Disability Policy Studies, Vol. 4, pp. 9-39.

Zomu't, Y. (1993), Vocational Rehabilitation of the Disabled, Press and Publications and the Church Council, Amman.

Zu'bi, A. (1991), Disabilities in Jordan: Characteristics and Some Demographic Factors, DSS, Amman. 


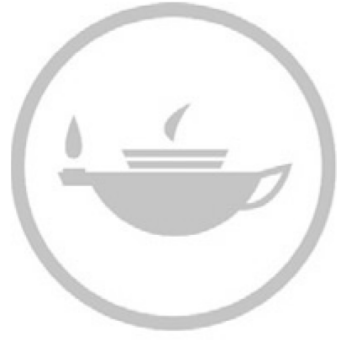

Taylor \& Francis
Taylor \& Francis Group http://taylorandfrancis.com 